\title{
İlkokul Yönetici ve Sınıf Öğretmenlerine Göre Suriyeli Sığınmacı Öğrencilerin Yaşadıkları Sorunlar ve Çözüm Önerileri $^{1}$
}

\section{According to Primary School Administrators and Classroom Teachers Syrian Refugee Student's Problems and Their Solutions}

\begin{tabular}{|c|c|}
\hline & Gizem ALKALAY ${ }^{2}$ Bilgen KIRAL ${ }^{3}$ Ali Riza ERDEM ${ }^{4}$ \\
\hline $\begin{array}{l}\text { Anahtar } \\
\text { Kelimeler } \\
\text { İlkokul, yönetici, } \\
\text { sinıf ögretmeni, } \\
\text { göç, } \\
\text { Suriyeli } \\
\text { sı̆ğınmacı } \\
\text { ögrenci. }\end{array}$ & 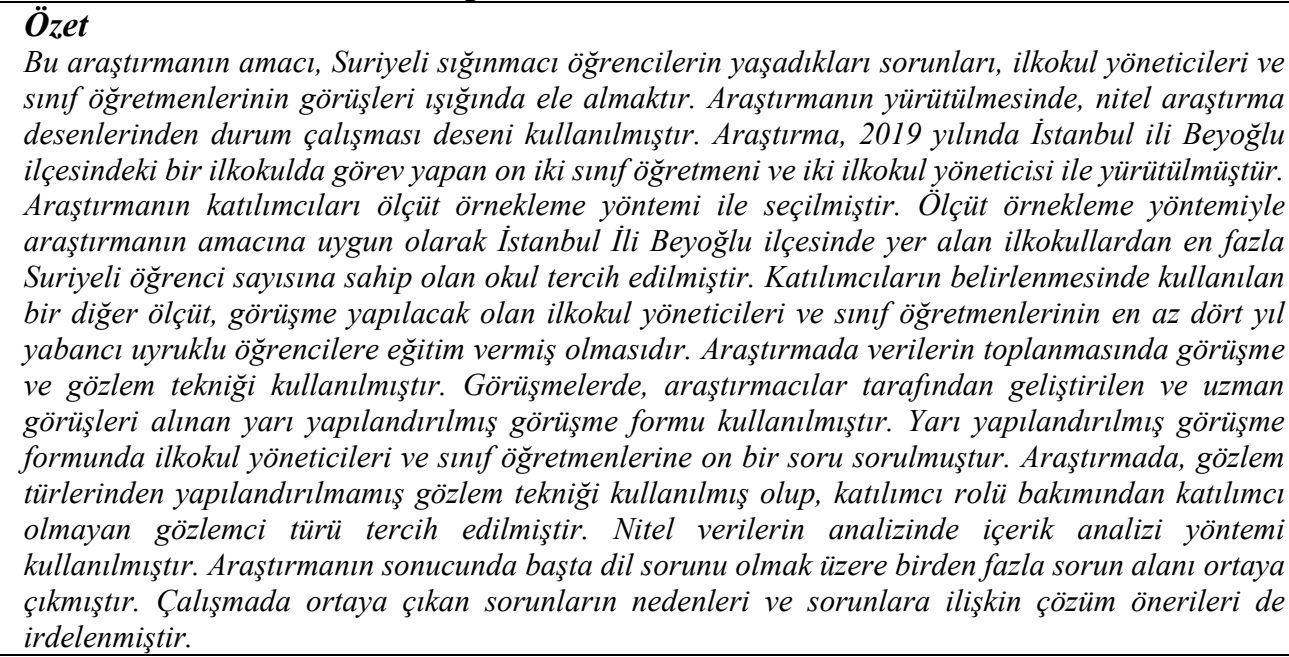 \\
\hline $\begin{array}{l}\frac{\text { Key Word }}{\text { Primary school, }} \\
\text { administrator, } \\
\text { primary school } \\
\text { teacher, } \\
\text { migration, } \\
\text { refugee Syrian } \\
\text { student. }\end{array}$ & $\begin{array}{l}\text { The aim of this research is to examine the problems of Syrian Refugee students who are at the public } \\
\text { school of in the light school primary school administrators' and teachers' opinions. The case study } \\
\text { design was used from the qualitative research design while conducting the research. The research } \\
\text { was carried out in 2019, twelve teachers and two primary school administrators working in the } \\
\text { primary school in Istanbul, Beyoğlu district. The participants of the study were selected by the } \\
\text { criterion sampling method. The school with the highest number of Syrian students in Beyoglu province } \\
\text { was preferred. The other criterion that is used in the formation of participants is that the teachers and } \\
\text { the primary school administrators who are going to have an interview would have given education to } \\
\text { the foreign students for at least four years. In the research, interview and observation techniques were } \\
\text { used to collect data. During the interview, a semi-structured interview form developed by the } \\
\text { researchers and approved by field experts was used. Eleven questions were asked to primary school } \\
\text { administrators and classroom teachers in the semi-structured interview form. In the research, the } \\
\text { unstructured observation technique was used from among observation techniques and non- } \\
\text { participative observation types were used in terms of the researchers' role. The content analysis } \\
\text { method was used in the analysis of qualitative data. As a result of the research, more than one problem } \\
\text { area has emerged, especially the language problem. The causes of the problems arising in the study } \\
\text { and suggestions for solutions to the problems are also examined. }\end{array}$ \\
\hline $\begin{array}{l}\text { Atıf için: } \\
\text { For Citation }\end{array}$ & $\begin{array}{l}\text { kalay. G., Kıral, B., \& Erdem, A. R. (2021). İlkokul yönetici ve sınıf öğretmenlerine göre } \\
\text { riyeli sığınmacı öğrencilerin yaşadıkları sorunlar ve çözüm önerileri. Muğla Sitkı Koçman } \\
\text { iversitesi Eğitim Fakültesi [MSKU Journal of Education], 8(1), 231-249. DOI: } \\
\text { 21666/muefd.809182 }\end{array}$ \\
\hline
\end{tabular}
Received: 12.10 .2020 Accepted: 21.02.2021 Published: 01.05.2021

\footnotetext{
${ }^{I}$ Bu çalışma, Gizem Alkalay'ın 2. ve 3. yazarların eş danışmanlığında, Aydın Adnan Menderes Üniversitesi Eğitim Yönetimi programında hazırlamış olduğu yüksek lisans tezinden üretilmiştir.

${ }^{2}$ Bilim uzmani, gizemalkalay.90@gmail.com,ORCID: 0000-0003-4553-7293

${ }_{3}^{3}$ Aydın Adnan Menderes Üniversitesi, Eğitim Yönetimi ABD, bilgen.kiral@adu.edu.tr, ORCID:0000-0001-5352-8552

${ }^{4}$ Aydın Adnan Menderes Üniversitesi, Eğitim Yönetimi ABD, arerdem@adu.edu.tr, ORCID: 0000-0001-9704-9529
} 
İnsanlık tarihinin tüm dönemlerinde çeşitli göçlerin yaşandığı bilinmektedir. İnsanlığın ortaya çıkışının Buzul Çağında başladığı ve buradan dünyanın dört bir yanına dağıldığı, birtakım irklara ayrıldığı varsayıldığında, göçün insanlık tarihi kadar eski olduğu ve insanoğlunun ayrılmaz bir parçası olduğu kabul edilmektedir (Tanoğlu, 1969). Bu sebeple insanlığın varoluşundan bu yana, insanla birlikte anılan en önemli kavramlardan birisi göçtür (Karakoç, 2011). İnsanların bir yerden başka bir yerleşim yerine, yaşamlarının bir kısmını veya tamamını, geçici bir süre için ya da kalıcı olarak yapılan, coğrafi yer değiştirme biçiminde ifade edilebilen göç (Bhugra, 2004); kişilerin muhtelif sebeplerle bulundukları bölgeden başka bölgelere gitmesidir. $\mathrm{Bu}$ durum sürekli olabileceği gibi geçici nitelikte de olabilmektedir. Göçler, mekânda eşitsiz biçimde dağıtılmış ekonomik firsatlardan yararlanma isteğinin bir sonucu olabildiği gibi ekolojik dayatmalar ya da devlet gibi sosyal bir otoritenin gündeme getirdiği sürgünler ve savaşlar gibi farklı nedenlerle de ortaya çıkabilmektedir (Terzi, 2012). Sayılan nedenlerden ötürü göçler birkaç tür sınıflamaya tabi tutulmaktadır. Bunlardan birincisi otorite ya da doğal bir zorlamadan ötürü "zorunlu göç" veya kişilerin kendi iradesiyle serbestçe gerçekleştirdikleri "gönüllü gö̧̧" niteliğinde olabilmektedir (Güllüpınar, 2012). İkinci sınıflama ise; iç göç ve dış göç şeklindedir. Bir ülkenin kendi sınırları içerisindeki bölgeler arasında gerçekleştirilen göç hareketi “iç göç”; bir ülkeden bir başka ülkeye yapılan göç ise "dı̧̧ göç” olarak tanımlanmaktadır (Sağlam, 2017). Hangi tür göç olursa olsun göçün ekonomik, toplumsal ve siyasal olmak üzere birçok sebebi, sonucunda da çeşitli etkileri bulunmaktadır.

Göçlerin, göç eden aileler üzerinde de birden fazla etkisi bulunmaktadır. Bundan en çok etkilenen grup da tabiî ki çocuklardır. Nitekim Türkiye böyle bir dış göç olayını 2011'den beri yaşamaktadır. Türkiye'nin komşuları arasında yer alan Suriye sınırları içerisinde meydana gelen iç savaş, işsizlik, yönetimin baskıcı uygulamaları ve gıda fiyatlarında yaşanan aşırı yükselişler nedeniyle başta genç gruplar olmak üzere, Suriyeli vatandaşlar çeşitli ülkelere göç etmeye başlamışlardır (Sayın, Usanmaz ve Aslangiri, 2016). Suriye'de yaşanan krizin ardından iç savaşın başlamasıyla Nisan 2011'den bu yana Türkiye'ye de Suriyeli sığınmacılar gelmektedirler. Suriye'de yaşanan bu gelişmeler neticesinde yaşanan kitlesel göç, dünyanın en büyük insani krizlerinden birisini ortaya çıkarmıştır. Bu kriz sonucu Birleşmiş Milletler'in (BM) raporuna göre altı milyona yakın Suriyeli evlerini terk ederek kendi ülke sınırları içerisinde güvenli bölgelere göç etmiş, dört milyona yakın insan ise ülke dışına göç etmek mecburiyetinde kalmıştır. Türkiye, Suriye ile geçmişe dayanan kültürel ve komşuluk bağlarını koruyarak toplu göç hareketinin başladığı günden itibaren "açık kapı politikası" uygulamış, dört yıl içinde en çok Suriyeliyi kabul eden ülke konumuna gelmiştir. Bu süreçte Türkiye açık kapı politikası izlemiş ve göç hareketine sınırlarını açık tutmuştur. Göç eden tüm Suriyelilerin \% 44'ü Türkiye'ye gelmiştir. Türkiye'ye göç eden Suriyelilerin sayısı her geçen gün artmaya devam etmektedir (Tunç, 2015). 2011 yılından itibaren Türkiye'ye gelen Suriyeli sığınmacıların yıllara göre dağılımı İçişleri Bakanlığ̣ Göç İşleri Genel Müdürlüğü (2019) verilerine göre Şekil 1'de verilmiştir.

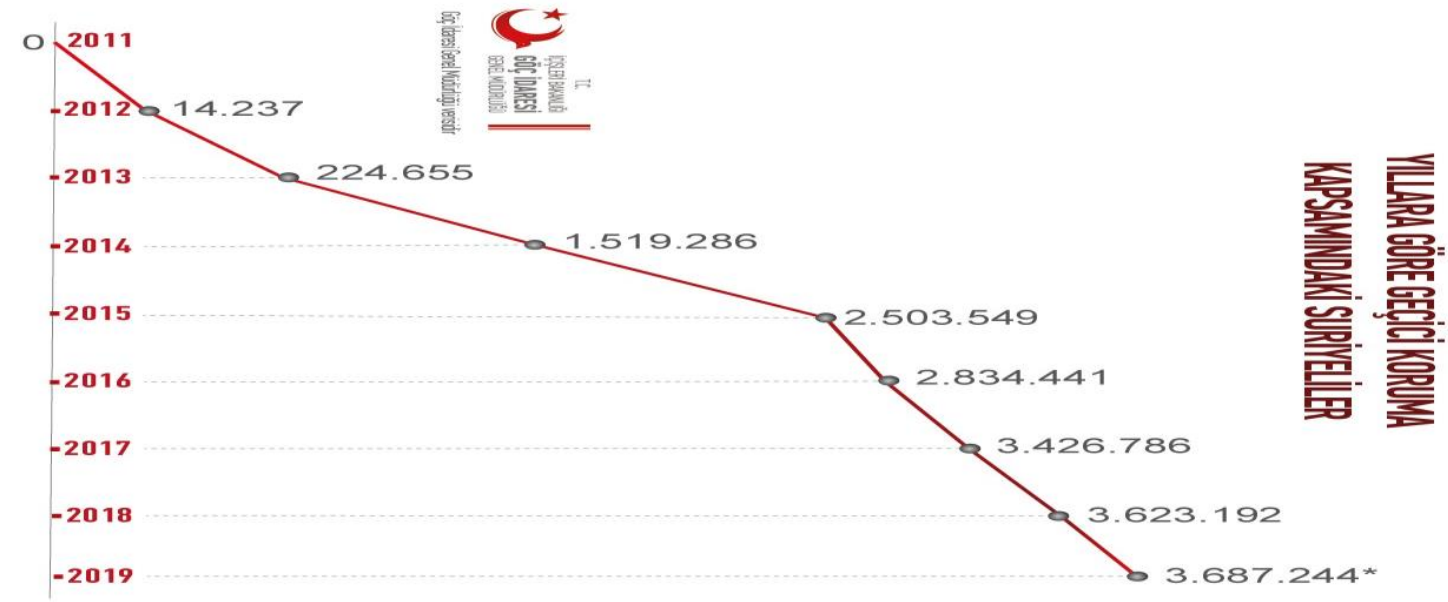

Şekil 1. Yıllara Göre Geçici Koruma Kapsamındaki Suriyeliler

Şekil 1'e göre geçici koruma kapsamında bulunan toplam Suriyeli sayısı, yıllara göre büyük oranda artış göstermiş̧tir. Bu artışın en fazla olduğu yıl aralığının 2015-2019 yılları arasında olduğu görülmektedir. İçişleri Bakanlığı Göç İdaresi Genel Müdürlüğü (GİGM) 21 Kasım 2019 tarihi itibarıyla 3.687.244 
olarak belirtilmektedir. Geçici koruma kapsamı altındaki öğrencilerin eğitim hizmetlerine ilişkin istatistikler incelendiğinde Nisan 2019 verilerine göre çağ nüfusunda 1.733.034 Suriyeli öğrenci bulunmakta olup, bunların 655.075'i (\% 62.53) eğitime erişebilmiştir (MEB, 2019). Bu istatistiklerde de görüldüğü gibi Suriyeli çocukların önemli bir kısmının hala eğitim hizmetlerine erişemediği söylenebilmektedir. İstanbul İl Milli Eğitim Müdürlüğ̈̈’nün (İstanbul İl MEM) 2017 y1lı verilerine göre İstanbul'da yaklaşı 130.000 okul çağ 1 nüfusunda Suriyeli öğrenci bulunmakta olup, bu öğrencilerin 29.000'i okullarda, 26.000'i ise Geçici Eğitim Merkezleri'nde eğitim görmektedir (İstanbul İl MEM, 2019).

Kayıtlı olan Suriye'den gelen göçmen ailelerin çocuklarının eğitim gibi hizmetleri Türkiye Cumhuriyeti tarafından karşılansa da; halen dil, barınma, sağlık ve eğitim gibi çok yönlü ihtiyaçları ve sorunları olduğu düşünülmektedir. Türk eğitim sistemi içerisinde yer alan Suriyeli öğrencilerin eğitim anlamında birçok sorunla karşılaştıkları yapılan alan yazın çalışmalarıyla (Akalın, 2016; Şensin, 2016 vb. gibi) da görülebilmektedir. Akalın (2016) tarafından yapılan araştırmada, Suriye'den gelen öğrencilerin arkadaşlarıyla kavga ve geçimsizlik yaşadığı, bu sorunu çözmek için öğretmenlerin herhangi bir kurumdan destek almadıkları ve öğrencilerin sorunlarını konuşarak çözmeye çalıştıkları bulgusuna ulaşmıştır. Araştırma kapsamında görüşüne başvurulan öğretmenlere göre öğrencilerin eğitim ve öğretimle ilgili sorunları; evde kendisine yardımcı olabilecek kimsenin olmaması ve öğrencinin kurs ve dershaneye gidememesi olarak tespit edilmiştir. Şensin'in (2016) araştırmasında öğrencilerin Türkçe bilmemelerinin eğitimlerinde bir problem teşkil ettiği, savaşın da etkisiyle sorunlu davranışlarda bulunan Suriyeli öğrencilerin yaşadıkları zorluklar sebebiyle akranlarıyla olan ilişkilerinin de olumsuz etkilendiği sonucuna ulaşılmıştır. Sağlam ve Kanbur (2017) sınıf öğretmenlerinin mülteci öğrencilere yönelik tutumlarını incelemek amacıyla yaptıkları araştırmada; dil ve kültürel problemler nedeniyle Suriyeli öğrencilerin eğitiminde yeterli düzeye ulaşılamadığı sonucuna ulaşılırken; Erdem (2017) ise öğretim sürecinde temel sorunun dil sorunu olduğunu ortaya çıkarmıştır. Başar, Akan ve Çiftçi (2018) mülteci öğrencilerin öğrenme sürecinde iletişim sorunu yaşadıkları, dil sorunu yaşadıkları için verilen mesajların mülteci öğrenciler tarafından anlaşılamadığı, öğrencinin kendini sınıftan soyutladığı ve bunun da uyum ve tutum sorunlarını ortaya çıkardığı gibi bulgulara ulaşmışlardır. Kardeş ve Akman (2018) ise Suriyeli çocukların Türkçe'yi öğrenme ve okula uyumla ilgili sorunlarının bulunduğunu, öğretmenlerin mülteci çocukların eğitiminde kendilerini yeterli hissetmediklerini, öğretmenlerin sınıf ortamında mülteci çocuklara yönelik düzenlemeye gitmediklerini, mevcut müfredatı çocukların eğitimi için yeterli görmediklerini tespit etmişlerdir. Ayrıca öğretmenler Suriyeli çocukların uyum problemlerinin çözümü için Türkçe dil eğitimi ve okul öncesi eğitim almaları gerektiğini de ifade etmişlerdir.

Almadani'nin (2018) araştırması ise Amerika Birleşik Devletleri’ndeki okullarda öğrenim gören Suriyeli mülteci öğrenciler üzerinde yürütülmüştür. Araştırmada, öğrencilerin eğitimsel ve sosyal deneyimlerini anlamak, yaşadıkları eğitimsel engelleri incelemek ve öğrencileri desteklemek amaçlanmıştır. Araştırmanın sonuçlarına göre; bu öğrencilerin geldiklerinde kültürel şok yaşadıkları, yaşadıkları ülkedeki deneyimlerinin Amerika'daki öğrenimlerini etkilediği, okulda 1rkçı baskılar olduğu, dil öğreniminde zorlandıkları, bu öğrencilerin eğitime entegre edilmesinde zorluklar olduğu, mülteci öğrencileri kapsayan bir sistemin ve kültürel hoşgörünün olması gerektiği vurgulanmıştır. Bunar (2019), Koehler ve Schneider (2019), Bajaj ve Bartlett (2017), Graham, Minhas ve Paxton (2016) gibi araştırmacıların farklı ülkelerde farklı milliyetten mülteci ögrencilerle yaptıkları çalışmalarda da benzer sorunlar yaşandığ 1 tespit edilmiştir.

Yapılan araştırmalarda da görüldüğü gibi hem diğer göçmenler hem de Suriyeli göçmen/sığınmacı öğrencilerin bir takım sorunlarının olduğu tespit edilmiştir. Fakat yapılan araştırmaların hiçbiri araştırmacıların örneklem kapsamına aldığı il ve ilçede yapılmamıştır. İstanbul ili Beyoğlu ilçesi gibi büyük ve kozmopolit bir ilçede yaşayan ve öğrenim gören öğrencilerin eğitim sorunlarının ortaya konulması, çözüm önerilerinin geliştirilmesi ve sorunların nedenlerinin irdelenmesinin ve çözüme kavuşturulmasının İstanbul'da öğrenim gören hem Suriyeli hem de diğer öğrenciler açısından gerekli olduğu söylenebilir. Ayrıca araştırmanın, elde edilen sonuçları doğrultusunda, desteğe ihtiyacı Suriyeli öğrencilere yardım etmek açısından önem arz ettiği; öğrencilerin sorunlarına çözüm bulmanın çocuk hakları meselesi olduğu da düşünülmektedir. Bu araştırma; Suriye'den dış göçle gelen ailelerin ilkokula devam eden çocuklarının yaşadıkları eğitim sorunlarının tespit edilmesi ve çözüm önerilerinin geliştirilmesi amacıyla yapılmıştır. Bu temel amaç çerçevesinde, araştırmada aşağıdaki sorulara yanıt aranmıştır. İlkokul yöneticileri ve sınıf öğretmenlerine göre Suriyeli öğrencilerin; 
1. Türk eğitim sisteminde yaşadıkları sorunlar nelerdir?

2. Yaşanılan sorunların altında yatan nedenler nelerdir?

3. Bu sorunlara getirilebilecek çözüm önerileri nelerdir?

\section{Yöntem}

Araştırmada, ilkokullarda öğrenim gören Suriyeli sığınmacı öğrencilerin, Türk eğitim sisteminde yaşadıkları sorunları ve çözüm önerilerini, ilkokul yöneticileri ve sınıf öğretmenlerinin görüşleri ışığında ayrıntılı ve derinlemesine ortaya koyabilmek amacıyla (Patton, 2014) nitel yaklaşım benimsenmiştir. Nitel araştırma; insan davranışını, içinde bulunduğu ortam içinde ve çok yönlü olarak anlamaya çalışmaktadır (Yıldırım ve Şimşek, 2016). Araştırmanın yürütülmesinde, nitel araştırma desenlerinden durum çalışması deseni kullanılmıştır. Durum çalışmaları; gerçek hayatta var olan durumu derinlemesine araştırmak, incelemek maksadıyla yapılmaktadır (Creswell, 2013). Nitel durum çalışmasının en temel özelliği bir ya da birkaç durumun derinliğine araştırılmasıdır. Bu araştırmada durum çalışması deseni kullanılarak, Suriyeli sığınmacı öğrencilerin yaşadıkları sorunlar ve çözüm önerilerine ilişkin ilkokul yöneticileri ve sınıf öğretmenlerinin görüş ve deneyimlerini derinlemesine ortaya koymak amaçlanmıştır.

\section{Katılımcilar}

Araştırma 2019 yılında İstanbul ili Beyoğlu ilçesinde gerçekleştirilmiş̧ir. Araştırmanın katılımcıları, amaçlı örnekleme yöntemlerinden ölçüt örnekleme yöntemi kullanılarak seçilmiştir. Bu örnekleme yöntemindeki temel anlayış önceden belirlenmiş bir dizi ölçütü karşılayan bütün durumların çalışılmasıdır. Burada sözü edilen ölçüt veya ölçütler araştırmacı tarafından oluşturulabilir ya da daha önceden hazırlanmış bir ölçüt listesi kullanılabilir (Yıldırım ve Şimşek, 2016). Ölçüt örnekleme yöntemiyle araştırmanın amacına uygun olarak çalışma grubunu belirlemek için öncelikle İstanbul ilindeki en fazla Suriyeli sığınmacı öğrencilerin bulunduğu ilçe tespit edilmiştir. Bu ilçe Beyoğlu ilçesidir. Ardından Beyoğlu ilçesinde yer alan ilkokullardaki en fazla Suriyeli öğrenci sayısına sahip olan okullar belirlenmiştir. Ayrıca araştırmanın katılımcılarının belirlenmesinde kullanılan bir diğer ölçüt ise görüşme yapılacak olan ilkokul yöneticileri ve sınıf öğretmenlerinin en az dört y1l yabancı uyruklu öğrencilere eğitim vermiş olmasıdır. $\mathrm{Bu}$ ölçütün belirlenmesinin sebebi, görüşülen katılımcıların öğrencilerin ilkokul gelişim düzeylerinin her birinde eğitim vermiş olmalarından dolayı deneyimli olmalarıdır (İlgili veriler alınan izinler doğrultusunda İçişleri Bakanlığı Göç İşleri Genel Müdürlüğü, İstanbul İl Milli Eğitim Müdürlüğü, Beyoğlu İlçe Milli Eğitim Müdürlüğünden edinilmiştir.). Araştırma kapsamında görüşülen ilkokul yöneticilerine ve sınıf öğretmenlerine Mert, Ayşe şeklinde kod isimler verilerek araştırma başlamıştır. Katılımcılara ait bilgiler Tablo 1'de verilmektedir.

Tablo 1

Katılimcilara Ait Bilgiler

\begin{tabular}{lllll}
\hline Katılımcı & Cinsiyet & Mesleki Kıdem (yıl) & Ĕgitim Durumu & Okuttuğu Sınıf \\
\hline Mert & Erkek & 13 & Lisans & 2.Sınıf \\
Can & Erkek & 12 & Lisans & 3.Sınıf \\
Mehmet & Erkek & 12 & Lisans & 3. Sınıf \\
Zeynep & Kadın & 11 & Lisans & 2.Sınıf \\
Burak & Erkek & 10 & Lisans & 4.Sınıf \\
Ahmet & Erkek & 10 & Lisans & 1.Sınıf \\
Buse & Kadın & 10 & Lisans & 3.Sınıf \\
Gizem & Kadın & 10 & Lisans & 4.Sınıf \\
Ayşe & Kadın & 9 & Lisans & 1.Sınıf \\
Mustafa & Erkek & 9 & Lisans & 4.Sınıf \\
Melisa & Kadın & 8 & Lisans & 1.Sınıf \\
Hatice & Kadın & 8 & Lisans & 2.Sınıf \\
Okan (Yönetici) & Erkek & 15 & Lisansüstü & - \\
Elmas (Yönetici) & Kadın & 13 & Lisans & - \\
\hline
\end{tabular}

Tablo 1'e göre her sınıf düzeyinden 6 erkek ve 6 kadın olmak üzere toplam 12 sınıf öğretmeni ve 1 kadın 1 erkek olmak üzere 2 ilkokul yöneticisiyle görüşme sağlandığı görülmektedir. Katılımcıların biri 
dışında hepsi lisans eğitimi mezunudur. Araştırma kapsamında görüşülen ilkokul yöneticisi ve sınıf öğretmenlerinin mesleki kıdemleri 8 ila 15 yıl arasında değişmektedir.

\section{Veri Toplama Araçları}

Araştırma ile ilgili sınıf öğretmenleri ve ilkokul yöneticilerinin deneyim ve görüşlerini ortaya çıkarmak amacıyla görüşme tekniği kullanılmıştır. Görüşmelerde, araştırmacılar tarafından geliştirilen yarı yapılandırılmış görüşme formu uygulanmıştır. Yarı yapılandırılmış görüşme tekniğinde; görüşmeler açık uçlu soruları içermekte olup; konunun açıklığa kavuşturulması için önceden belirlenmiş olan sorular veya sorunlardan (Merriam, 2015) oluşan, yarı yapılandırılmış görüşme formunun kullanılması tercih edilmiştir. Hazırlanan görüşme sorularına ilişskin Eğitim Yönetimi alanında uzman altı kişinin görüşlerine başvurulmuştur. Araştırmada iç geçerliğin sağlanabilmesi amacıyla uzman incelemesi yapılmıştır. Alan uzmanı tarafindan görüşme soruları ve pilot uygulama sonucunda elde edilen veriler incelenmiş ve gerekli kısımlar düzeltilmiştir. Araştırmada tutarlılı̆̆ın sağlanabilmesi için görüşme sonucunda araştırmacılar tarafindan yapılan kodlamalar, alan uzmanı tarafından kontrol edilmiştir. Uzman görüşü ile yapılan düzenlemeler sonucunda görüşme formuna son hali verilmiştir.

Yürütülen araştırmada kullanılan bir diğer veri toplama aracı gözlem yöntemidir. Gözlem, araştırmada ihtiyaç duyulan verilerin insan, toplum ya da doğa gibi belli hedeflere odaklanılarak çıplak gözle ya da bir araç kullanarak izlenmesi ile veri toplanması sürecini tanımlamaktadır. Gözlem yaparken gözlenenler doğal ve açık bir yöntemle izlenmekte, kaydedilmekte, tanımlanmakta, analiz edilmekte ve yorumlanmaktadır (Büyüköztürk, Çakmak, Akgün, Karadeniz ve Demirel, 2014). Gözlem tekniği, gözlenilenlerin kendi doğal ortamları içinde bulunması ve bu şekilde birçok davranışın objektif olarak belirlenmesine (Karasar, 2014) olanak sağlaması nedeniyle, bu araştırmada kullanılmak için tercih edilmiştir. Araştırmada, gözlem türlerinden yapılandırılmamış gözlem tekniği kullanılmış olup, katılımcı rolü bakımından katılımcı olmayan gözlemci türü tercih edilmiştir. Katılımcı olmayan gözlemci türünün tercih edilmesinin nedeni gözlemcinin hiçbir etkisi olmadan katılımına (Büyüköztürk vd., 2014) olanak sağlamasıdır. Yapılan gözlemler, her sınıf düzeyinden birer derste olmak üzere dört sınıf gözlemini ve teneffüslerde yapılan üç bahçe gözlemini içermektedir. Gerçekleştirilen sınıf gözleminde Suriyeli öğrencilerin ders esnasındaki davranışları, derse katılım durumları incelenmiş, bunlarla ilgili notlar alınmıştır. Teneffüs gözlemlerinde de Suriyeli öğrencilerin davranışları ve arkadaşlık ilişkileri gözlemlenmiş ve gerekli notlar alınmıştır. Bu gözlemlerde Suriyeli öğrencileri tespit etmek amacıyla öğretmenlerden yardım alınmıştır.

\section{Verilerin Toplanması ve Analizi}

Verilerin toplanmasında ilkokul müdürüyle yapılan görüşme müdür odasında, müdür yardımcısıyla yapılan görüşme müdür yardımcısının kendi odasında, sınıf öğretmenleriyle yapılan görüşmeler ögretmenler odası, toplantı salonu ve boş sinıflarda gerçekleştirilmiştir. Görüşmelerde ses kaydı alınmasına izin verilmediğinden kullanılmamış olup, sorulara verilen yanıtlar not tutularak alınmıştır. Verilerin analizinde ilkokul yönetici ve sınıf öğretmenleriyle yapılan görüşmeler sonucunda elde edilen veriler, bilgisayar ortamında metin haline dönüştürülmüştür. Metinlerde araştırmanın başında belirlenmiş olan sorular ana tema olarak alınmıştır. Veri analizini kolaylaştırmak açısından oluşturulan kodlar, bir liste halinde sıralanarak, kod listesi oluşturulmuştur. Kodlaması yapılan metinler, alan uzmanı tarafından kontrol edilerek, gerekli düzeltmeler yapılmışıı. Verilerin analizi, içerik analizi yöntemiyle yapılmıştır. İçerik analizi, toplanan verileri açıklayabilmek amacıyla birbirine benzeyen verileri belirli kavramlar çerçevesinde bir araya getirmek ve bunları okuyucunun anlayacağı biçimde düzenleyerek yorumlamaktır. İçerik analizinde kullanılan tekniklerden biri kodlama yapılmasıdır. Kodlama, kendi içinde anlamlı bir bütün oluşturan bölümlerin, araştırmacı tarafından tanımlayıcı sözcük ya da sözcük gruplarıyla isimlendirilmesidir (Yıldırım ve Şimşek, 2016).

\section{Geçerlik ve Güvenirlik}

Nitel veri analizinde inandırıcılığın ve tutarlılığın sağlanabilmesi, kodlayıcılar arasında uzlaşmanın sağlanmasıyla mümkün olmaktadır. Kodlayıcılar arasında uzlaşma, elde edilen verilerin iki ya da daha fazla araştırmacı tarafından kodlanması ve bu kodlamalar arasındaki tutarlılığın kontrol edilmesiyle yapılmaktadır (Creswell, 2017). Araştırmada görüşmeler sonucunda elde edilen veriler araştırmacı ve alan uzmanı tarafından ayrı zamanlarda kodlanmış ve yapılan kodlamalar karşılaştırılmıştır. Miles ve Huberman (1994) tarafından geliştirilen formülü kullanılarak araştırmanın güvenirliği \%82 bulunmuştur. Miles ve Huberman' a (1994) göre uzlaşma yüzdesinin \%70'in üstünde bir değer almas1, 
araştırmanın güvenilir olduğunu göstermektedir. Buradan yola çıkarak veri analizi sonucunda güvenilir bir sonuç elde edildiğini söylemek mümkündür.

Araştırmada geçerliliğin sağlanabilmesi açısından ayrıntılı betimleme kullanılarak, katılımcıların görüşlerinden doğrudan alıntılara yer verilmektedir. Ayrıntılı betimleme; içerik hakkında yeterli bilginin verilmesi, ham verinin ortaya çıkan kavram ve temalara göre yeniden düzenlenmiş bir biçimde okuyucuya yorum katmadan ve verinin doğasına mümkün olduğu ölçüde sadık kalınarak aktarılmasıdır. Doğrudan alıntılar bu amaçla araştırmacılar tarafından sık kullanılır (Gruba ve Lincoln, 1982). Bu araştırmada verilerin niteliğini desteklemek amacıyla veri kaynaklarının çeşitlemesi yönteminin basamaklarından olan gözlem verilerinin görüşme verileriyle karşılaştırılması tekniği kullanılmıştır. Veri çeşitlemesi, aynı sosyal olguya ait farklı koşullarda elde edilmiş verilerin karşılaştırılması olarak ifade edilebilir. Aynı araştırma sorusuna ait farklı nitelikteki veriler birbirlerinin denetimine, karşılaştırılmasına ve doğrulanmasına olanak sağlamaktadır (Patton, 1990 akt. Türnüklü, 2001).

\section{Araştırmacıların Rolü}

Araştırmada, görüşmeler sonucunda elde edilen veriler, ilkokul yöneticileri ve sınıf öğretmenlerinin görüşleri kod adlarla, doğrudan alıntılar verilerek aktarılmıştır. Gözlem verileri açıklanırken ortam tanımları yapılmış, sınıfın doğal ortamı ve dersin işleyişi okuyucuya objektif olarak aktarılmaya çalışılmıştır. Araştırmacı katılımcı rolü üstlenmemiş olup gözlem ve görüşmeler sonucunda elde edilen veriler mümkün olduğunca doğal ortam yansıtacak şekilde açıklanmaya çalışılmıştır. Araştırmanın yürütüldügü süreçte etik kurallara sadık kalınmış ilkokul yöneticileri ve sınıf öğretmenleriyle yapılan her bir görüşmeden önce kendilerine açılama yapılmıştır. Araştırma sonucunda elde edilen veriler tarafsız bir şekilde aktarılarak çalışma oluşturulmuştur. Araştırmaya başlamadan önce İstanbul İl Milli Eğitim Müdürlüğü’nden araştırma izni ile Aydın Adnan Menderes Üniversitesi Eğitim Araştırmaları Etik Kurulu'nun 25.12.2018 tarih ve 2018/13 sayılı kararı ile etik kurul onayı alınmıştır.

\section{Bulgular}

Araştırmada görüşme ve gözlem yoluyla elde edilen veriler, temalar ve alt temalar halinde incelenmiş ve bu bölümde açıklanmıştır.

\section{Suriyeli Öğrencilerin Yaşadıkları Sorunlar}

Suriyeli öğrencilerin yaşadıkları sorunlara ilişkin ilkokul yöneticileri ve sınıf öğretmenlerinin görüşleri temalara ve alt temalara ayrılarak, aşağıda Şekil 2'de verilmiştir.

Şekil 2'de görüldüğü gibi Suriyeli öğrencilerin yaşadıkları sorunlar ana temasına ilişkin ilkokul yöneticileri ve sınıf öğretmenlerine sorulan sorulara alınan yanıtlar ışığında veriler dört alt temaya ayrılmıştır. Bu temalar; eğitimsel sorunlar, veli kaynaklı sorunlar, okul-aile işbirliğine ilişkin sorunlar, davranışsal sorunlar şeklindedir. $\mathrm{Bu}$ alt temalardan biri olan eğitimsel sorunlara ilişkin ilkokul yöneticileri ve sınıf öğretmenlerinin görüşleri aşağıdaki gibidir.

“... Ë̆itimdeki en baştaki sorun dil sorunu. Çocuklar bizim dilimizi bilmedikleri için okumaya geçmeleri de bir hayli zaman alıyor. Okuma-yazmayı geç ögrendikleri için diğer dersleri de anlamaları geç oluyor. Okuma-yazma ögrendikten sonra dersleri anlamaları daha kolaylaşlyor tabi ama özellikle matematik dersinde başarllı değiller. (Ahmet Öğretmen)"

“... Birincisi, sınıflardaki yaş dağılımı farklı. Ben 4. Sinıfları okutuyorum, bu seviyede Suriyeli öğrencim de var, 12-13 yaşında Suriyeli ögrencim de var. Orta 3'e gitmesi gereken ögrenci de 4. Sinıfta. Bilişsel gelişim olarak yaş farkı ĕgitimi olumsuz yönde etkiliyor. Büyük olan çocuğun sınıf arkadaşları ile olan iletişimini de etkiliyor. Çocuk kendini o sınıfa ait hissetmeyince isteksizlik oluşuyor. (Burak Öğretmen)"

“... Evet, bir sürü sorun var, mesela matematik ve fen derslerinde çok zorlanıyorlar, ama sinavlar tüm ögrencilere aynı, bu yüzden çocuklar sınavda başarısız oluyorlar. (Hatice Öğretmen)”, 

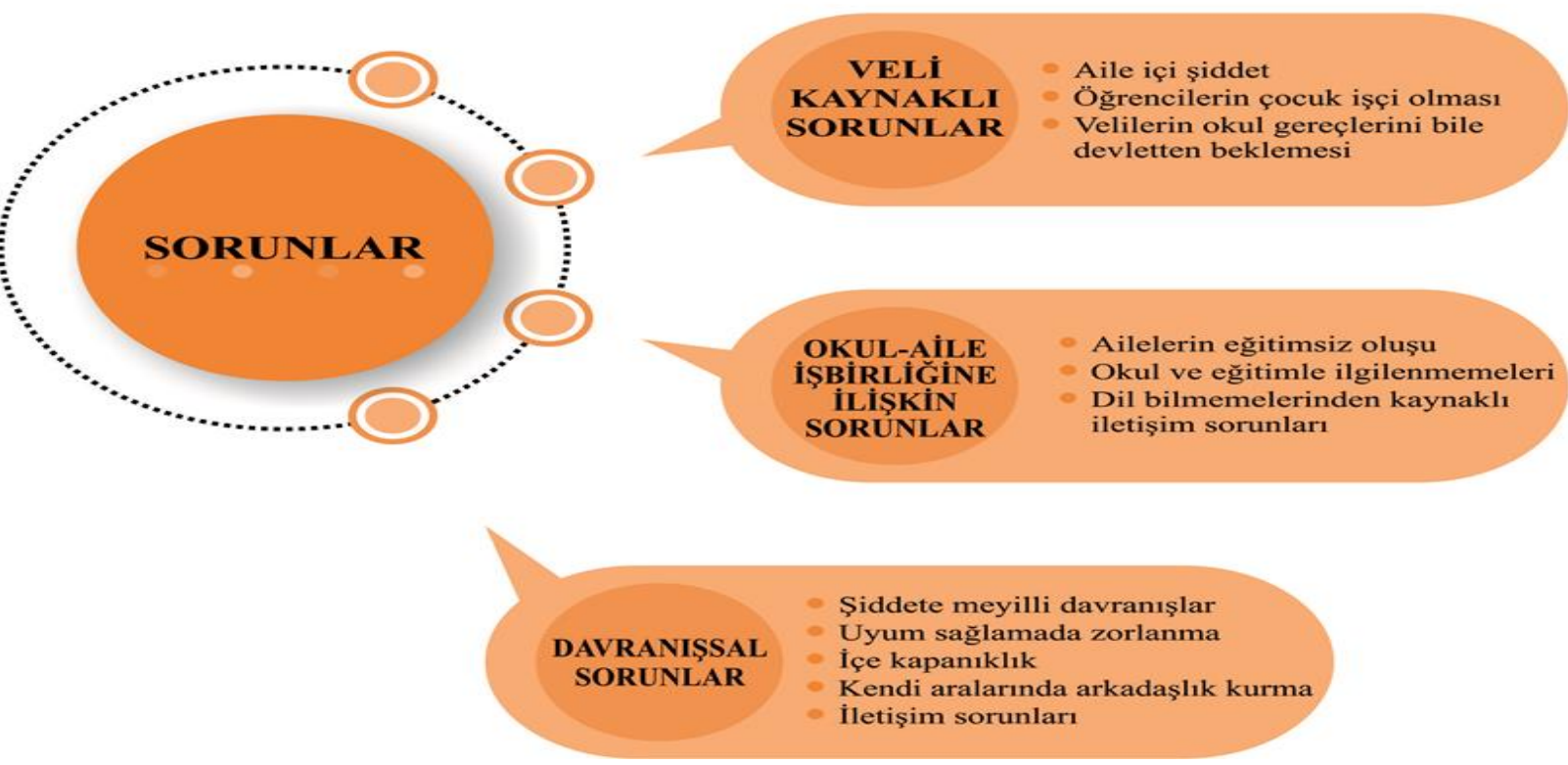

Şekil 2. Suriyeli Öğrencilerin Yaşadıkları Sorunlar

Sınıf öğretmenleri eğitimsel olarak karşılaştıkları en önemli sorunun dil sorunu olduğunu belirttikleri gibi, görüşülen sınıf öğretmenlerinin büyük çoğunluğu bu öğrencilerin yaşlarına göre sınıflarda eğitim alamamalarının ilerleme sağlama konusunda önemli bir sorun olduğunu belirtmişlerdir. Görüşülen sınıf öğretmenleri ve ilkokul yöneticileri Suriyeli öğrencilerin çoğunlukla derslerde başarısız olduklarını belirtmişlerdir. Araştırmaya katılan sınıf öğretmenleri ve ilkokul yöneticileri sadece Suriyeli öğrencilerin değil bulundukları okuldaki Türk öğrencilerin de başarı düzeylerinin yüksek olmadığını belirtmişlerdir. Belirlenen eğitimsel sorunları ortaya çıkaran birden fazla neden bulunmaktadır. Eğitimsel sorunları ortaya çıkaran bu nedenler, oluşturulan bir diğer tema olan "Sorunlarına Altında Yatan Nedenler" temasında irdelenmiştir. Yaşanılan sorunları açıklamak için oluşturulan bir diğer alt tema olan veli kaynaklı sorunlara ilişkin ilkokul yöneticileri ve sınıf öğretmenlerinin görüşleri aşağıdaki gibidir.

\footnotetext{
“... Evde şiddet gören, bir sürü soruna şahit olan, şiddete meyilli çocuklar oldukları için okulda verilen ĕgitim evde işlemiyor. (Buse Öğretmen)."

“... Bizim okulumuzda bakanlık tarafindan gönderilen İlkokullarda İileştirme Programı uygulandı. (IYEP) RAM'li olmayan ama başarısı düşük olan ögrencileri tespit etmek için, Türkçe ve matematik testi yapıld. Mesela 3. Sinıf düzeyine 1. Ve 2. Sinıf düzeyinde sorular soruldu. Bu sinavin sonucunda başarısız olan ögrencilerin \%98'ini Suriyeli ögrrenciler oluşturuyordu. Burada da gördügümü̈z gibi karnı aç olan, evde dayak yiyen, öz bakım becerileri bile gelişmemiş ve pis bir ortamda yaşayan çocuktan oturup evde ders çalışmasın bekleyemiyorsunuz. Bizim okul olarak verdiğimiz eğitim evde duvara tosluyor. (Yönetici Elmas)"
}

Veli kaynaklı sorunlara ilişkin ilkokul yöneticilerinin ve sınıf öğretmenlerinin görüşleri, sağlıklı bir ev ortamının olmayışı, ekonomik sıkıntılar yüzünden kalabalık evlerde yaşamak zorunda kalmaları ve şiddete maruz kalan çocukların varlığı üzerinde yoğunlaşmaktadır. Eğitimi olumsuz etkilediği belirtilen bir sorun alanı da okul-aile işbirliğine ilişkin sorunlar olmuştur. Bu alt tema için ilkokul yöneticilerinin ve sınıf öğretmenlerinin görüşleri aşağıdaki gibidir.

“... Okula gelip çocuğunun durumunu soran ya da toplantıya katılan Suriyeli ebeveyn çok az. Kendi sinufinda bir ögrrencimin ailesini hiç görmediğim için ziyarete gittim. Durum gerçekten vahimdi. Küçücük 
evde bir sürü insan, temizlik yok, çocuğun kendine ait bir odası zaten yok, aile ilgisiz ama bu çocuk yine o şartlarda bile çabalıyor. Oraya gidince daha iyi anladım neden başarılı olamadıklarını. (Mehmet Ögretmen)",

Görüşülen sınıf ögrretmenleri ve ilkokul yöneticileri ailelerin eğitimle ilgilenmediklerini okula gelmedikleri ve çocuklarının eğitimine destek olmadıkları için öğrencilerin öğrenimlerinin olumsuz yönde etkilendiğini belirtmişlerdir. Görüşmeler sonucunda elde edilen veriler ışığında, ortaya çıkarılan bir başka sorun alanı ise davranışsal sorunlar olmuştur. Bu alt temaya yönelik ilkokul yöneticilerinin ve sınıf ögretmenlerinin görüşleri aşağıdaki gibidir.

“... Gözlemlediğim bir diğer sorun ise davranış problemleri, hırçın davranışları oluyor çoğunlukla, onları da anlamak gerek geldikleri ve devamında yaşadıklarl şartlar bir çocuğun kaldırabileceği türden şeyler değil. Bu yüzden onlar da şiddete meyilli bir savunma mekanizması gelişmiş. Hatta oyunları bile birbirine tekme atarak oynuyorlar. Davranışsal olarak çoğu şiddete meyilli iken bazı öğrenciler de kendilerini iletişime kapatıyorlar. Bunu yapan genellikle kız ögrenciler. Kalabalık oldukları için Türk ögrenciler ile arkadaşlık kurmadan önce kendi aralarında kuruyorlar. Bir süre sonra kaynaşıyorlar tabi. (Gizem Ögretmen)"

Araştırma kapsamında görüşülen bütün sınıf öğretmenleri ve ilkokul yöneticileri Suriyeli öğrencilerin şiddete meyilli davranışlar sergilediklerini, savunma mekanizmalarını şiddet göstererek sergilediklerini belirtmişlerdir. Bu öğrencilerin geldikleri şartların ve burada yaşadıkları şartların kolay olmadığını, bu nedenle öğrencilerin içe kapanık davranışlar sergilediklerini söylemişlerdir. Savaş görmüş çocuklar ve hatta yakınlarını kaybetmiş çocuklar oldukları için kendilerini davranışsal olarak ifade etme konusunda zorluklar yaşadıklarını düşündüklerini belirtmişlerdir.

\section{Sorunların Altında Yatan Nedenler}

İlkokul yöneticileri ve sınıf öğretmenlerinin Suriyeli öğrencilerin yaşadıkları sorunlara ilişkin görüşlerinin ardından yaşanılan sorunların altında yatan nedenler ana temasına ilişkin görüşme sorularına verdikleri yanıtlar için Şekil 3 oluşturulmuştur. Aşağıda sorunların altında yatan nedenler ana temasına ilişkin bulgular, ilkokul yöneticileri ve sınıf öğretmenlerinin kendi ifadeleriyle desteklenerek Şekil 3'te açıklanmaktadır.
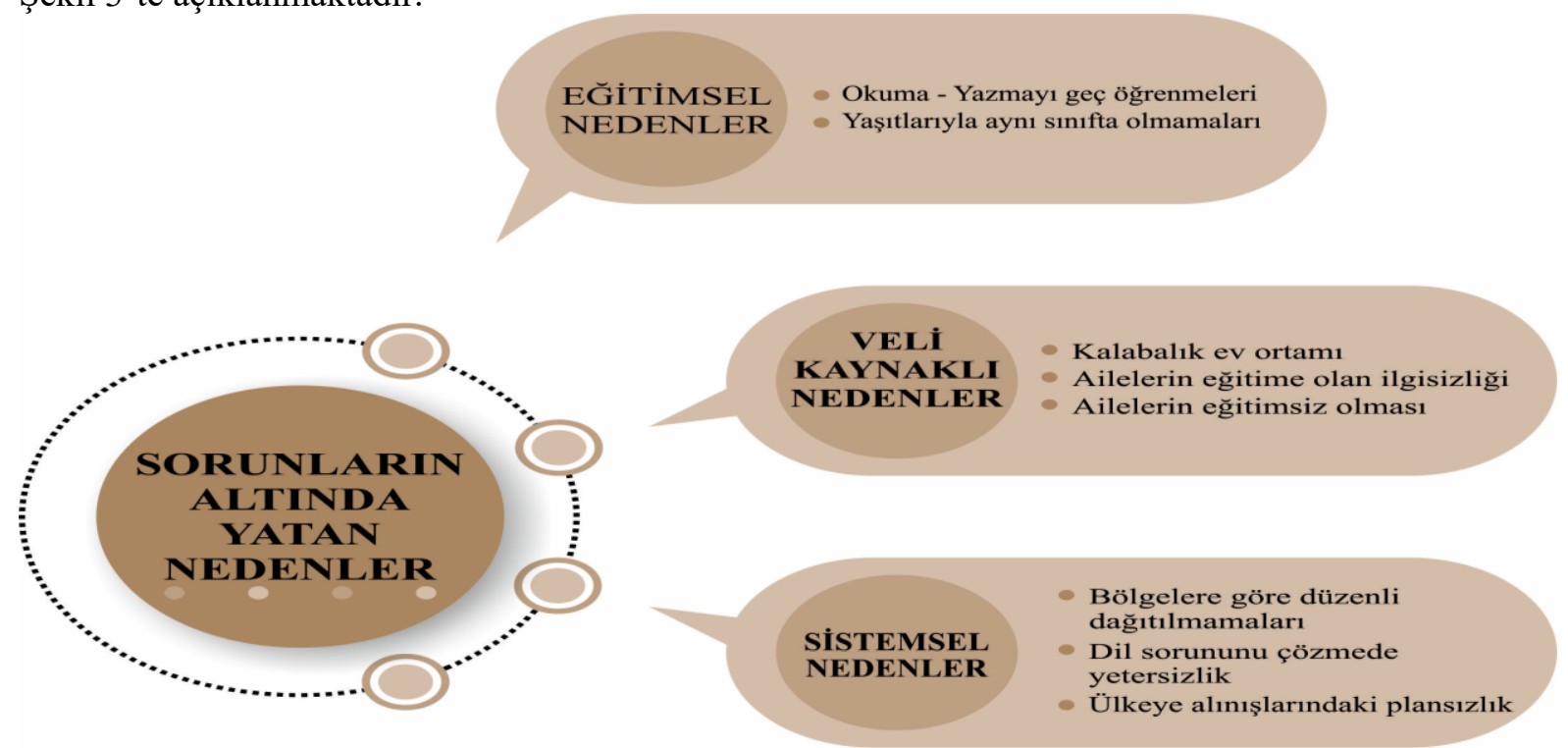

Bölgelere göre düzenli dağıtılmamalar

Dil sorununu çözmede yetersizlik

Ülkeye alınışlarındaki plansızlık

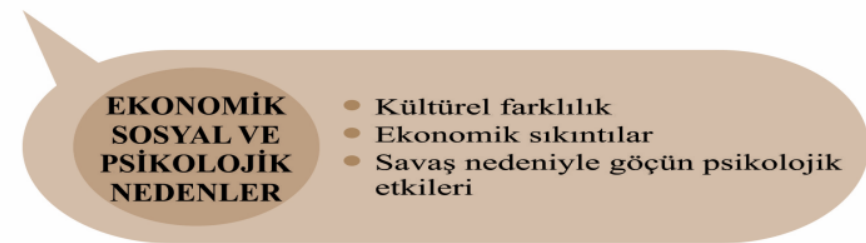

Şekil 3. Sorunların Altında Yatan Nedenler

Şekil 3'e göre araştırma kapsamında elde edilen bulgular doğrultusunda oluşturulan ikinci ana tema olan, sorunların altında yatan nedenlere ilişkin ilkokul yöneticileri ve sınıf öğretmenlerinin görüşleri 
araştırma sonucunda elde edilen kodlamalarla sunulmuştur. Yöneltilen görüşme sorularına karşıllık alınan yanıtlar çerçevesinde eğitimsel nedenler, veli kaynaklı nedenler, sistemsel nedenler ve ekonomik, sosyal ve psikolojik nedenler olmak üzere dört farklı alt tema oluşturulmuştur. Bu alt temalardan biri olan eğitimsel nedenlere ilişkin ilkokul yöneticileri ve sınıf öğretmenlerinin görüşleri aşağıdaki gibidir.

“... Az da olsa dil eğitimi verilmeden okullara gönderildikleri için okuma yazma öğrenmeleri zor oluyor. 3 sınıfa gelmiş daha tam okuyup yazamayan ögrencilerim var. Bunun çocukların başarılı olmalarını olumsuz yönde etkileyen bir neden olduğunu düşünüyorum. (Zeynep Öğretmen) "”

“... Yaşı büyük okula gelmiş olsa bile dil bilmediği için bir sınıftan başlamak zorunda oluyor bu çocuklar. Bu yüzden sınıfa adapte olmaları zorlaşıyor. Akranlar ile ĕgitime başlayabilseler daha kolay öğrenirler diye düşünüyorum. (Mert Öğretmen)"

Araştırmaya katılan bu iki sınıf öğretmeni de öğrencilerin dil öğrenmede yaşadıkları güçlüklerin, eğitimde meydana gelen sorunların nedeni arasında yer aldığını düşündüklerini belirtmişlerdir. Araştırmada elde edilen veriler ışığında oluşturulan bir diğer alt tema olan veli kaynaklı nedenlere ilişkin ilkokul yöneticileri ve sınıf öğretmenlerinin görüşleri aşağıdaki gibidir.
“... Aslında nedenlerin ana kaynağl göç etmiş olmaları. Keyfi bir şekilde göç etmedikleri için birçok psikolojik sorunu da beraberinde getiriyorlar. Birkaç aile birden aynı evde yaşlyorlar, maddi durumları çok kötü. Evde şiddet gören ögrencilerimiz var. Durum böyle olunca temel ihtiyaçlar yeterince karşılanmadığı için sıra eğitime gelmiyor. Biz burada ne kadar öğretmeye çalışsak da eve gidince aynı olduğundan yol alabilmemiz çok sıkıntı oluyor. Bir diğger nedeni ise ailelerin umursamaz ve eğitimsiz oluşu. Onlar için okul çocukların gidip vakit geçirdikleri bir yer. Bence sorunların nedenleri çocuklardan önce ailelerde başllyor. (Gizem Öğretmen)"

Görüşme sorularına verdikleri yanıtlarda sınıf öğretmenleri, sorunların kaynaklarından birinin de çocukların aile ortamlarında var olan sıkıntılar ve velilerin ilgisizliği olduğunu belirtmişlerdir. Velilerin çocuklarına karşı ilgisiz davranışları, öğrencilerin davranış problemleri geliştirmelerine neden olduğu söylenebilmektedir. Sorunların altında yatan nedenler ana temasını açıklamak için oluşturulan bir diğer alt tema olan sistemsel nedenlere ilişkin ilkokul yöneticileri ve sınıf öğretmenlerinin görüşleri aşağıdaki gibidir.

“... Bu konu için şunu söylemem gerek, ülkeye alınışları düzenli olmadığı için okullara dağıtıllş̧ları da düzenli ve programl olmad. Önce belli kamplarda eğitim alıp okullara gönderilselerdi biz de bu kadar ögretim zorluğu yaşamazdlk. (Ayşe Öğretmen)"

“....Bizim okulumuzda yabancı uyruklu öğrencilere Türkçe eğitimi vermek için çalı̧̧an ögretmenler var. Dersler dışında bu öğrencileri alıp eğitim veriyorlar ama bu ögrencilerin sayısı çok fazla olduğu için bu yeterli gelmiyor. Bu durumda eğitimlerde aksamalara neden oluyor. (Can Öğretmen)"

Görüşülen sınıf öğretmenleri Suriyeli öğrencilerin sayılarının fazla olduğu için dil sorununu çözmede yetersiz kaldıklarını belirtmişler ve okullara dağıtılışlarındaki düzensizliği bir neden olarak söylemişlerdir. Araştırma sorularına katılımcıların verdiği bu yanıtlar ışığında, Suriyeli öğrencilerin eğitim sorunlarının ortaya çıkmasına etki eden bir faktörün de uygulanan eğitim politikaları olduğu söylenebilmektedir. İlkokul yöneticileri ve sınıf öğretmenlerinin görüşlerine göre oluşturulan bir diğer alt tema olan ekonomik, sosyal ve psikolojik nedenlere ilişkin görüşler aşağıdaki gibidir.

“... Aslında nedenler birbirine geçmiş halkalardan oluşmakta. Öncelikle tabi ki savaştan gelen çocuklar olduklarl için savaşın verdiği psikolojik etki çok büyük. (Yönetici Elmas)”

Sorunların altında yatan nedenler ana teması için alınan yanıtlar incelendiğinde ilkokul yöneticileri ve sınıf öğretmenlerinin çoğunluğunun anlattıkları sorunlarla nedenlerin iç içe geçmiş kavramlar olduğunu belirttikleri ortaya çıkmıştır. Bu konuya vurgu yapan ilkokul yöneticileri ve sınıf öğretmenlerinin görüşleri şu şekildedir.

“... Aslında sorunlart söylerken nedenlerinden de bahsetmiş oldum. Bence bu sorunların temel sebepleri geldikleri ve yaşadıkları şartlar ve dil sorunu. Bunlar davranışlarını ve eğitimlerini etkiliyor. (Burak Ögretmen)"

“... Aslına bakarsanız eğitimde karşılaştığımız sorunlar bir başka sorunun nedenini oluşturuyor. Örneğin ögrenci dil öğrenmede güçlük yaşadı̆̆ı ve sınıfa kendini ait hissetmediği için içe kapanık davranıyor, ders çalışmıyor bu durum da başarısız olmasının bir nedeni olmuş oluyor. (Yönetici Elmas)"” 


\section{Sorunlara İlişkin Çözüm Önerileri}

İlkokul yöneticileri ve sınıf öğretmenlerinin sorunların altında yatan nedenlere ilişkin görüşlerinin ardından sorunlara ilişkin çözüm önerileri ana temasına yönelik görüşme sorularına verdikleri yanıtlar hazırlanmış olan Şekil 4 ile verilmiştir. Aşağıda sorunlara ilişkin çözüm önerileri ana temasına yönelik bulgular, ilkokul yöneticileri ve sınıf öğretmenlerinin kendi ifadeleriyle desteklenerek Şekil 4'te açıklanmaktadır.

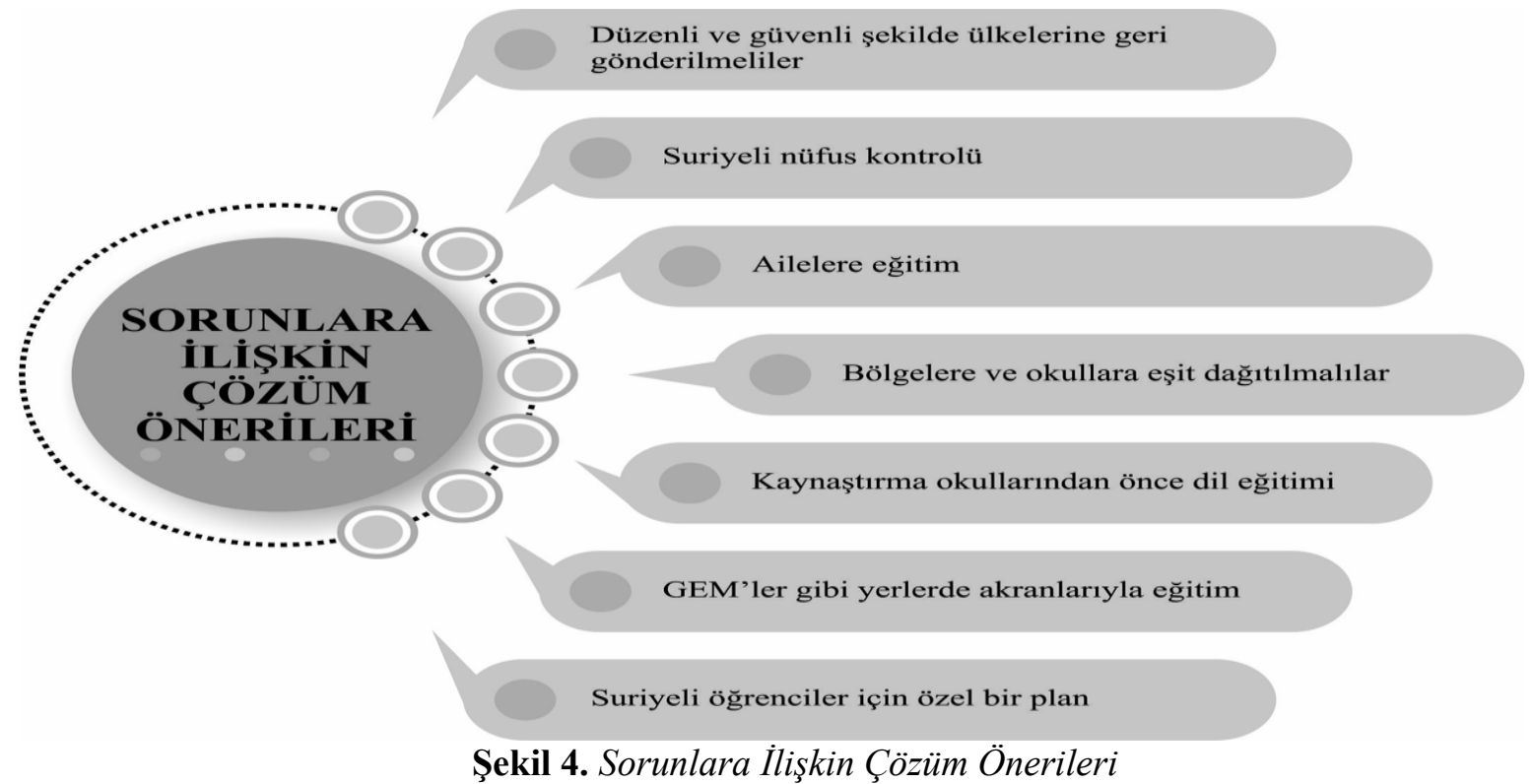

Şekil 4'te görüldüğü gibi araştırma sonucu elde edilen sınıf öğretmenleri ve ilkokul yöneticilerinin görüşleri 1şığında oluşturulmuş olan sorunlara ilişkin çözüm önerileri ana temasını açıklamak amacıyla yedi farkl1 çözüm önerisine ulaşılmıştır. Bu çözüm önerilerinden biri olan düzenli ve güvenli bir şekilde geri gönderilmeliler konusunda sınıf öğretmenleri ve ilkokul yöneticilerinin görüşleri aşağıdaki gibidir.

“... Açık söylemek gerekirse bir an önce ülkelerine dönmeleri gerekiyor. Bu kadar kalabalık bir slğınmacı grubunun ülkemiz için güvenli olmadiğını düşünüyorum. (Ayşe Öğretmen)”

“... Suriyeliler geçici koruma kapsamında ülkeye alındılar. Statüleri böyle. Onların bizim kültürümüze, yaşam şeklimize uyum göstermeleri gerekiyor. Bizler bu yönde çaba harclyoruz. Ancak ben özellikle ailelerin bu uyuma çok da yanaştıklarını görmedim. Her ne kadar eğitim vermeye çalışsak da kendi istedikleri şekilde davranmaya ve yaşamaya devam ediyorlar. Bu duruma benim çözüm önerim ise düzenli ve güvenli bir şekilde ülkelerine geri gönderilmeleri.(Gizem Öğretmen)"”

Araştırma kapsamına görüşülen sınıf öğretmenlerinin çoğunluğunun çözüm önerisi olarak Suriyeli nüfus kontrolünü bir çözüm önerisi olarak belirttikleri ortaya çıkmıştır. Konuya ilişkin sınıf öğretmenlerinin görüşleri aşağıda verilmiştir.

“...Ülkemizde gittikçe sayısı artan Suriyeli nüfus var. Bunların kontrol altında tutulması gerektiğini düşünüyorum. (Zeynep Öğretmen)”

“... Kendilerinden olan bir sürü aile ve çocuk olduğu için bizim kültürümüze ve eğitimimize alışmaya çalışmak yerine, küçük bir Suriye kasabası oluştu burada. Hem okullara yı̆̆llma olmadan dă̆ıtılmalı hem de nüfus kontrolü yapılmalı bence. (Ahmet Ögretmen)"

Araştırma kapsamında görüşülen ilkokul yöneticileri ve sınıf öğretmenlerinin çözüm önerisi olarak üzerinde durdukları bir diğer konu ise ailelere eğitim verilmesi gerekliliğidir. Konuya ilişkin ilkokul yöneticileri ve sınıf öğretmenlerinin görüşleri aşağıdaki gibidir.

“...Çözüm olarak şunu söylemem gerekir ki önce ailelerin eğitilmesi gerekiyor. Çünkü bu çocuklar aile içi şiddete maruz kalıyorlar, aynı odada anne ve babasının özel ihtiyaçlarına şahit oluyorlar. Doğal olarak onların oturup evde ders çalışabilecekleri bir ortam olmuyor. Burada ögrendikleri etik kurallar, toplumsal yaşama adapte olma becerileri, temizlik, güzel konuşma gibi şeyler eve gidince başa dönüyor. Biz onların eğitimleri konusunda kısır bir döngü içerisine giriyoruz. (Yönetici Elmas)" 
“... Aklıma ilk gelen çözüm önerisi ailelerin bilinçlendirilmesi gerektiği. Suriyeli öğrencilerimizin çoğunun ailesi çocuklarına önem vermiyorlar. Okulda ne yaptıklarını hiç umursamıyorlar. Durum böyleyken çocuklara verdiğimiz ĕgitim eksik kallyor diye düşünüyorum. (Mert Öğretmen)"”

Araştırma kapsamında görüşülen tüm sınıf öğretmenleri ve ilkokul yöneticilerinin çözüm önerisi olarak belirttikleri bir diğer konu ise öğrencilerin bölgelere ve okullara eşit dağıtılması gerektiği yönünde görüşleridir. Bu çözüm önerisine yönelik görüşler aşağıdaki gibidir.

\begin{abstract}
“...Bu okulda Türkiye’deki birçok köy nüfusundan fazla Suriyeli ögrenci var. Bir de bunların ailelerini düşünün düşünebiliyor musunuz? Bölgelere yönelik çalışma yapılması gerekiyor. Bir okulda 10-15 tane Suriyeli ögrenci varsa bizim gibi okullarla az Suriyeli ögrenci sayısına sahip okullardaki çalışmaların aynı olmamasi gerekiyor. (Burak Öğretmen)"

“... Okulumuzun bulunduğu bölge ekonomik düzeyi düşük olan ailelerin yaşayabilmesi için uygun bir bölge olduğundan Suriyeli nüfus bu bölgede çok fazla. Bu yüzden okulumuzdaki Suriyeli ögrenci sayısı da çok fazla. Bu konuda çözüm Suriyeli ögrencilerin bir okula bu kadar ylğllma olmadan civar okullara paylaştırılması olmalıdır. (Yönetici Okan)”
\end{abstract}

Yürütülen araştırmada görüşülen tüm sınıf öğretmenleri ve ilkokul yöneticilerinin Suriyeli öğrencilerin kaynaştırma okullarına gönderilmeden önce akranlarıyla dil eğitimi almalarının gerekli olduğu yönünde fikir birliğinde oldukları ortaya çıkmıştır. Bu konuya ilişkin sınıf öğretmenleri ve ilkokul yöneticilerinin görüşleri aşağıdaki gibidir.

“...Kaynaştırma projesinde bir okul olarak dersler dışında Suriyeli öğrencilere dil ĕgitimi veren ögretmenlerimiz var. Ancak bu yeterli gelmiyor, ögrenciler dil öğrenme konusunda geride kallyorlar. Bizim okullarımıza gönderilmeden önce dil ĕgitimi verilmesi gerekiyor. (Can Öğretmen)”

“... En çok üzerinde durulması gereken konu öğrencilerin dil sorununu hızlı bir şekilde çözmek. Bunu sağlayabilmek için okullara gönderilmeden önce bunlar için oluşturulan kamplarda eğitim almaları gerektiğini düşünüyorum. (Yönetici Okan)"

Araştırma sonucunda ortaya çıkan bir diğer çözüm önerisi Suriyeli öğrenciler için özel bir plan uygulanması gerektiği yönünde olmuştur. Konuya ilişkin sınıf öğretmenleri ve ilkokul yöneticilerinin görüşleri aşağıdaki gibidir.

“... Göçle gelen ögrencileri bizim müfredatımıza tabi tutmadan önce farklı bir program uygulanırsa faydalı olacağını düşünüyorum. Öğrencilerin hazır bulunuşluklarını iyileştirmemiz gerekiyor. (Mehmet Ögretmen)"

“... Suriyeli ögrrencileri direkt olarak Türk müfredatına sokmak bence yanllş. Öncelikle dil ve kültüre alıştırılmaları için farklı bir ĕgitim programı uygulanması gerektiğini düşünüyorum. (Ahmet Öğretmen)”,

Araştırmanın yürütüldüğü okul İstanbul Beyoğlu ilçesinde olup, sosyo-ekonomik düzeyi orta seviyede olan ailelerin yaşadığ olduğundan oldukça fazla Suriyeli nüfusa sahip bir bölgede yer almaktadır. Çalışılan okul oldukça kalabalık olup, okulda bulunan Suriyeli öğrenci sayısı ilkokul ve ortaokul olmak üzere toplam 600'dür. Görüşülen sınıf öğretmenleri ve ilkokul yöneticileri yalnızca Suriyeli öğrencilerin değil okulun genelinin başarı düzeyinin düşük olduğunu öğrencilerin ve ailelerin eğitim konusunda isteksiz ve ilgisiz olduklarını belirtmişlerdir.

\title{
Gözlem Raporları
}

Araştırmanın bu kısmında Suriyeli öğrencilerin yaşadıkları sorunları doğal ortamında görebilmek amacıyla yapılmış olan gözlemlerden elde edilen bulgular, rapor halinde açılanmaya çalışılmıştır. Her bir sınıf düzeyinde ve teneffüslerde yapılan gözlemler olmak üzere toplam altı adet gözlem raporu bulunmaktadır. Gözlemler sonucunda elde edilen bulgular, ilkokul yöneticileri ve sınıf öğretmenlerinin görüşleriyle de desteklenmiştir. Aşağıda her bir sınıf düzeyi ve teneffüs gözlemlerine verilen örnekler tablolar halinde sunulmaktadır.

\section{Sinıf Gözlem Raporu}

Bu kısımda 1. Sınıf dersinde yapılan gözlem, sınıf ortamı ve dersin işleyişini olduğu gibi anlatarak açıklanmaya çalışılmıştır. Yapılan ilk gözlem ilkokul 1.sınıf gözlemi olup; alınan notlar aşağıdaki Tablo 2'de verilmiştir. 
Tablo 2

Illkokul 1. Sinıf Gözlem Raporu

Tarih: 21.05.2019

Saat: $13: 30-14: 10$

Ders: Türkçe

Gözlem Konusu: Suriyeli Öğrencilerin Yaşadıkları Sorunlar

Gözlem yapılan sınıfın mevcudu 30 öğrenciden oluşmaktadır. Gözlem yapıldığı sırada sınıfta bulunan öğrenci sayısı 24 olup bunlardan 5 tanesi Suriyeli öğrencidir. Öğrenci sıraları üç sıra halinde arka arkaya düzenlenmiştir. Sıraların tümü, tahtanın sağ tarafında yer alan öğretmen masanı görecek şekilde yerleştirilmiştir. Sınıfta akıllı tahta mevcuttur.

Sınıf öğretmeni sınıfa girdi, "günaydın çocuklar" dedi ve masasına elindekileri bıraktı. Ardından öğrencilerine okuma yaptıkları kitabı çıkarmalarını söyledi. Öğrenciler kitaplarını çıkarırken öğretmen sınıfta sıralar arasında dolaşmaya başladı. Öğrencilerin hepsi kitaplarını çıkardıktan sonra öğretmenin seçtiği bir öğrenciden okuduğu kitaptan anladıklarını anlatmasını istedi. Öğrenci anlatırken biraz heyecanlı bir ses tonuyla konuşmaya başladı. Diğer öğrenciler arkadaşlarını dinlerken konuşmaya ve sessiz şekilde gülüşmeye başladı. Gözlenen Suriyeli öğrenciler öğretmen söz vermeden konuşmadı. Suriyeli öğrencilerden yan yana oturan iki tanesi ders boyunca konuşup gülüştüler. Bu şekilde birkaç öğrenci daha kitaplarını anlattıktan sonra sınıf öğretmeni, Suriyeli bir kız öğrenciden kitabını anlatmasını istedi. Bu öğrenci ayağa kalkarak kısık bir ses tonuyla anladıklarını anlatmaya başladı. Suriyeli öğrencinin Türkçe'yi iyi konuşamadığı ve çok çekingen davrandığı gözlendi. Gözlenen diğer Suriyeli öğrenciler arasında arkadaşıyla alay eden bir öğrenci yoktu. Sınıfta bulunan Suriyeli öğrencilerin, dersin akışını bozacak bir davranışta bulundukları gözlemlenmemiştir. Ders boyunca gürültü yapan öğrenciler olduğu gözlemlendi. Dersin devamında sınıf öğretmeni, okumada güçlük çeken öğrencilerine yardımcı olarak onların yanına gidip okuma yaptırdı. Sınıf öğretmeninin yanına gittiği öğrencilerin iki tanesi Suriyeli öğrenciydi. Dersin bitiminde sınıf öğretmeni ödevleri vererek ellerinde bulunan kitapları bitirmelerini söyledi.

Tablo 2'de ilkokul birinci sınıfta yapılan gözlemde, gözlenen Suriyeli öğrencilerin okumada güçlük çektikleri görülmüştür. Suriyeli öğrenciler arasında el kaldırarak söz isteyen bir öğrenciye rastlanmamıştır. Dersin genel akışını bozacak davranışlarda bulundukları gözlemlenmemiştir ancak dersin tamamında da sessiz durmamışlar kendi aralarında konuşmuşlardır. Kendi aralarında konuşurlarken bir sorun yaşamayan Suriyeli öğrencilerden birine söz verildiğinde kelimeleri söylerken dilinin dönmediği kelimeler olduğu gözlemlenmiştir. Söz verilen Suriyeli öğrenci kısık bir ses tonuyla konuşmuştur.

\section{Sinıf Gözlem Raporu}

Bu kısımda 2. Sınıf dersinde yapılan gözlem, sınıf ortamı ve dersin işleyişini olduğu gibi anlatarak açıklanmaya çalışılmıştır. Yapılan ikinci gözlem olan 2. Sınıf gözleminde alınan notlar Tablo 3'te verilmiştir.

Tablo 3'de görüldüğü gibi ders işlenirken dersin düzenini bozacak bir davranışta bulunan Suriyeli öğrenciye rastlanmamıştır. Öğrencilerin genel olarak kendi aralarında konuştukları gözlemlenmiştir. Yalnızca bir Suriyeli öğrenci sürekli konuştuğu için sınıf öğretmeninden uyarı almıştır. Derse katılım sağlayan, el kaldırarak söz isteyen Suriyeli öğrenciye rastlanmamıştır.

Tablo 3

Illkokul 2. Sinuf Gözlem Raporu

Tarih: 21.05.2019

Saat: 14:20-15:00

Ders: Hayat Bilgisi

Gözlem Konusu: Suriyeli Öğrencilerin Yaşadıkları Sorunlar

Gözlem yapılan sınıfın mevcudu 26 öğrenciden oluşmaktadır. Gözlem yapıldığı sırada sınıfta bulunan öğrenci sayısı 20 olup bunlardan 4 tanesi Suriyeli öğrencidir. Öğrenci sıraları üç sıra halinde arka arkaya düzenlenmiştir. Sıraların tümü, tahtanın sağ tarafında yer alan öğretmen masanı görecek şekilde yerleştirilmiştir. Sınıfta akıllı tahta mevcuttur.

Sınıf öğretmeni "merhaba çocuklar" dedi. Sınıf öğretmeni akıllı tahtayı açarak "bugün doğal afetler konusunu öğreneceğiz" dedi. Öğrencilerinden kitaplarındaki belirttiği sayfayı açmalarını istedi. Akıllı tahtada konuyla ilgili bir açıklama yazısı açtı ve doğal afetler konusunu anlatmaya başladı. Sınıf öğretmeni dersi anlatırken ögrencilerden uğultular halinde sesler duyulmaktaydı. Dersin 15. Dakikasından sonra uğultular yükselince sınıf öğretmeni sessiz olmaları için öğrencilerini uyardı. Dersin ilerleyen dakikalarında gözlenen Suriyeli öğrencilerin dersi dinledikleri görülmüştür. Sınıf öğretmeni doğal afetlerden deprem konusunu anlatmaya başlarken akıllı tahtadan konuyla ilgili bir görsel açtı ve öğrencilerine deprem hakkında neler biliyorsunuz diye 
sordu. Sınıfta el kaldıran toplam öğrenci sayısı 6 kişiydi ve bunlar arasında Suriyeli öğrenci yoktu. Dersin devam eden seyrinde de söz almak isteyen Suriyeli öğrenciye rastlanmamıştır. Gözlenen Suriyeli öğrencilerden bir tanesi sürekli konuştuğu ve dersi dinlemediği için öğretmenden uyarı almıştır. Dersin sonunda sınıf öğretmeni öğrencilerinden bir sonraki ders için doğal afetlerle ilgili görseller getirmelerini istemiştir.

\section{Sinıf Gözlem Raporu}

Bu kısımda 3. Sınıf dersinde yapılan gözlem, sınıf ortamı ve dersin işleyişini olduğu gibi anlatarak açıklanmaya çalışılmıştır. Yapılan üçüncü gözlem olan ilkokul 3. Sınıf gözleminde alınan notlar Tablo 4 'te verilmiştir.

Tablo 4

Illkokul 3. Sinuf Gözlem Raporu

\begin{tabular}{l}
\hline Tarih: 30.05.2019 \\
Saat: 13:30-14:10 \\
Ders: Matematik \\
Gözlem Konusu: Suriyeli Öğrencilerin Yaşadıkları Sorunlar \\
Gözlem yapılan sınıfın mevcudu 30 öğrenciden oluşmaktadır. Gözlem yapıldığı sırada sınıfta bulunan öğrenci \\
sayısı 26 olup bunlardan 6 tanesi Suriyeli öğrencidir. Öğrenci sıraları üç sıra halinde arka arkaya düzenlenmiştir. \\
Sıraların tümü, tahtanın sağ tarafında yer alan öğretmen masanı görecek şekilde yerleştirilmiştir. Sınıfta akıllı \\
tahta mevcuttur. \\
Sı̈ıf öğretmeni sınıfa girdikten sonra akıllı tahtayı açtı. Akıllı tahta açılırken öğrencilerine geçen ders verdiği \\
ödevleri göstermelerini söyledi. Öğrenciler ödevlerini çıkarırken sı̈ıfta fazla gürültü olmadığı gözlendi. \\
Gözlenen Suriyeli öğrencilerden 3 tanesi ödevlerini tam yapmamışlardı. Sınıf öğretmeni tüm sınıfın ödevlerini \\
tek tek kontrol etti ve ödevlerini tam yapan öğrencilerin defterlerine imza attı. Öğrencilere anlamadıkları \\
sorularını sormalarını istedi ve sıralar arasında dolaşarak öğrencilerinin çözemedikleri soruları tespit etti. Bunun \\
ardından tek tek öğrencileriyle beraber soruları tahtada çözmeye başladı. Tahtaya çıan öğrenciler arasında 2 \\
Suriyeli öğrenci de vardı. Bu Suriyeli öğrencilerin tahtada soruyu yanıtlarken oldukça sessiz oldukları \\
gözlemlendi. Sınıf öğretmeni sorunun cevabını anlatırken, öğretmenin komutlarına göre yazdılar ve yerlerine \\
geçtiler. Dersin devamında sını öğretmeni akıllı tahtadan çevre hesaplamayla ilgili örnek problemlerin olduğu \\
bir ekran açtı, ekranda her problem ardından konu anlatımlı cevapları vardı. Sınıf öğretmeni öğrencilerine önce \\
soruyu okuyor ardından öğrencilerinin çözmesini ve cevap vermesini bekliyordu. Öğgrenciler soruyu çözmeye \\
çalıştıkları sırada, sınıftan uğultular geliyordu. Dersin devamı soru çözümleriyle devam etti. Gözlenen Suriyeli \\
öğrencilerin soruları çözmekte çaba gösterdikleri görülmüştür. Çözemedikleri sorular için sınıf öğretmeninden \\
yardım istemişlerdir ve akıllı tahtada soru çözümleri açılanırken dikkatle dinleyip defterlerine yazdıkları \\
gözlemlenmiştir.
\end{tabular}

Tablo 4'te görülüğü gibi ders esnasında gözlenen Suriyeli öğrencilerin, ödevlerini yapmadıkları, soru çözümü için gönüllü olup el kaldırmadıkları gözlemlemiştir. Dersin genel akışında huzuru bozacak bir davranışta bulundukları gözlemlenmemiştir. Tahtaya kalkan öğrencilerin sessizce sınıf öğretmeninin komutlarını yerine getirdikleri görülmüştür. Soru çözümleri yapılırken Suriyeli öğrencilerin çaba gösterdikleri ve yapamadıklarında sınıf öğretmenine sordukları gözlemlenmiştir. Gözlenen Suriyeli öğrencilerin, sınıfa uyumsuz davranmaları, kendilerini soyutlamaları gibi davranışlar görülmemiştir. Suriyeli ögrencilerin grup halinde oturdukları gözlemlenmiştir.

\section{Sinıf Gözlem Raporu}

Bu kısımda 4. Sınıf dersinde yapılan gözlem, sınıf ortamı ve dersin işleyişini olduğu gibi anlatarak açıklanmaya çalışılmıştır. Yapılan dördüncü gözlem olan ilkokul 4. Sınıf gözleminde alınan notlar Tablo 5 'te verilmiştir.

\section{Tablo 5}

\section{Illkokul 4. Sinıf Gözlem Raporu}

Tarih: 30.05.2019

Saat: 14:20-15:00

Ders: Matematik

Gözlem Konusu: Suriyeli Öğrencilerin Yaşadıkları Sorunlar

Gözlem yapılan sınıfın mevcudu 30 öğrenciden oluşmaktadır. Gözlem yapıldığı sırada sınıfta bulunan öğrenci sayısı 20 olup bunlardan 4 tanesi Suriyeli öğrencidir. Öğrenci sıraları üç sıra halinde arka arkaya düzenlenmiştir. Sıraların tümü, tahtanın sağ tarafında yer alan öğretmen masanı görecek şekilde yerleştirilmiştir. Sınıfta akıllı tahta mevcuttur. 
Sınıf öğretmeni "merhaba çocuklar" dedi. Elindekileri masasına bırakıp akıllı tahtayı açarken öğrencilerine, bugün alan ölçümleriyle ilgili problemlerin nasıl çözüldüğünü öğreneceklerini belirtti. Ardından öğrencilerinden defterlerini çıkarmalarını istedi. Sınıf Ö-öğretmeni alan ölçümleriyle ilgili kısa bir konu anlatımı yaparken önemli noktaları öğrencilerine not aldırdı. Gözlenen Suriyeli öğrencilerden üçü notları dikkatlice yazarken birinin öğretmeni dinlemediği ve not almadığ gözlemlendi. Ardından sınıf öğretmeni öğrencileriyle birlikte soru cevap şeklinde problem çözümlerine başladı. Problem çözümleri yapılırken sınıfta el kaldıran öğrencilerin oldukça fazla olduğu gözlemlendi. Öğrenciler derse katılıyor ve soruları çözmek için gayret gösteriyorlard1. Gözlenen Suriyeli öğrencilerden biri ders esnasında sorulan 3 soruyu arkadaşlarından önce çözüp el kaldırarak gönüllü bir şekilde soruyu nasıl çözdüğünü anlattı. Suriyeli öğrencinin soru çözümünü anlatırken akıcı bir şekilde konuştuğu ve kendini ifade etmede güçlük yaşamadığı görülmüştür. Gözlenen diğer Suriyeli öğrenciler söz alarak soru çözümüne katılmamış sadece soruları çözmeye çalışıp not almışlardır. Dersin sonunda sınıf öğretmeni öğrencilerine teşekkür ederek ödev vermediğini belirtmiştir.

Tablo 5'e göre, ders işleyişinde sınıfın düzenini bozan Suriyeli öğrenciye rastlanmamıştır. Sınıfta bulunan Suriyeli öğrencilerin genel olarak dersi dinledikleri, yalnızca birinin derse ilgisiz kaldığ gözlemlenmiştir. Derse katılım olarak Suriyeli öğrencilerin ilgili oldukları gözlemlenmiştir.

\section{Teneffüs Gözlem Raporu}

Bu kısımda teneffüslerde yapılan gözlemler bahçe ortamı ve öğrenci davranışlarını olduğu gibi anlatarak açıklanmaya çalışılmıştır. Yapılan beşinci gözlem teneffüs gözlemi olup; alınan notlar Tablo 6'da verilmiştir.

\section{Tablo 6}

\section{Teneffüs Gözlem Raporu}

Tarihler: 21.05.2019 - 30.05.2019

Gözlemin Konusu: Suriyeli Öğrencilerin Yaşadıkları Sorunlar

Okulun bahçesi yüksek duvarlarla çevrili geniş bir bahçedir. Gözlem yapılan bahçede giriş kapısı büyük, siyah demirden bir kapı. Kapıdan girişin sol tarafında bekçi kulübesi yer almaktadır. Bahçe girişinin hemen karşısında okul giriş kapısı vardır. Bahçenin iki tarafında basketbol potaları mevcuttur. Okul bahçesi ağaçlık yeşil alandan çok betonla kaplıdır. Okulun nüfusu fazla olduğundan teneffüsler oldukça kalabalık geçmektedir.

Teneffüs gözlemlerinde okulun bahçesi ve çevresi dolaşıldıktan sonra görüş açısı uygun bir bölgede gözlemler yapılmıştır. Teneffüslerde nöbetçi olan öğretmenlerin öğrencileri etkin bir şekilde kontrol ettiği görülmüştür. Gözlenen Suriyeli öğrencilerin, oyun oynadıklarından çok etrafta koşturdukları, erkeklerin birbirlerini kovaladıkları kız çocuklarının ise bir köşede konuştukları ya da bahçede dolaştıkları gözlemlenmiştir. Türk öğrencilerle vakit geçiren Suriyeli öğrenciler varken, yalnızca kendi uyruklarından olan çocuklarla vakit geçiren Suriyeli öğrencilerin olduğu da gözlemlenmiştir. Suriyeli öğrencilerin kendilerine özgü bir oyun oynadıkları gözlemlenmemiştir. Dersin başlangıcı geldiğinde nöbetçi öğretmenlerin Suriyeli öğrencileri sınıfa girmeleri konusunda uyardıkları görülmüştür.

Tablo 6'da görüldüğü gibi Suriyeli öğrencilerin kavga ettikleri ya da şiddete meyilli bir davranış sergiledikleri gözlemlenmemiştir. Çoğunlukla etrafta koşuşturan Suriyeli öğrencilerin olduğu gözlemlenmiştir. Teneffüslerde nöbetçi öğretmenlerin, etkin bir şekilde öğrencilerini kontrol ettikleri görülmüştür. Araştırmada yapılan gözlemler genel olarak değerlendirildiğinde öğretmenlerin görüşlerini teyit eder biçimde olduğunu söylemek mümkündür.

\section{Tartışma ve Sonuç}

İlkokul yöneticileri ve sınıf öğretmenlerine göre Suriyeli sığınmacı öğrencilerin Türk eğitim sisteminde yaşadıkları sorunların belirlenmesi amacıyla yürütülen araştırmanın ilk alt amacında Suriyeli sığınmacı öğrencilerin yaşadıkları sorunlar incelenmiştir. Araştırmanın sonucunda ilkokul yöneticileri ve sınıf öğretmenlerinin görüşlerine göre Suriyeli öğrencilerin yaşadıkları sorunlar içinde önde gelen sorunun dil sorunu olduğu ortaya çıkmıştır. Bu sonuçlara benzer olarak Graham, Minhas ve Paxton (2016), Bunar (2019) ve Almadani (2018) tarafından yapılan araştırmalarda da mülteci öğrencilerin dil öğreniminde sorunlar yaşadıkları tespit edilmiştir. Ortaya çıkan dil sorununun yanı sıra eğitimsel, davranışsal ve veli kaynaklı olmak üzere birden fazla sorun alanı da ortaya çıkmıştır. Araştırmanın sonucuna uygulanan eğitim politikaları kaynaklı ortaya çıkan eğitimsel sorunlar çerçevesinde bakıldığında, ilkokul yöneticileri ve sınıf öğretmenlerinin görüşlerine göre dil sorununun yanı sıra en çok üzerinde durulan sorun Suriyeli öğrencilerin yaşlarına göre sınıflara yerleştirilmediği ve bölgelere eşit sayıda öğrenci dağılımı yapılmadığı söylenebilmektedir. Bunun sonucunda öğrencilerin uyum sorunu yaşayıp, 
kendilerini sınıf arkadaşlarından soyutladıkları ve bu durumun öğrenme süreçlerini olumsuz yönde etkilediği ortaya çıkmıştır. Suriyeli öğrencilerin sayısının fazla olmasından dolayı kendi aralarında arkadaşlık kurmaları da uyum süreçlerini olumsuz yönde etkileyen bir sorun olarak ortaya çıkmıştır. Eğitimsel sorunlar nedenleriyle birlikte ele alındığında, Suriyeli öğrencilerin uyumsuz davranışlarının da öğrenme süreçlerini olumsuz yönde etkilediği söylenebilmektedir. Bunların yanı sıra araştırmanın sonucunda öğrencilerin, Türk müfredatına alışmakta zorlandıkları ve çoğunlukla başarısız oldukları gibi sorunlar da ortaya çıkmıştır. Benzer bir sonuç olarak Bajaj ve Bartlett (2017) araştırmasında mülteci öğrenciler için müfredat düzenlemesinin gerekliliği üzerinde durmuşlardır.

Araştırma sonucunda elde edilen sonuçlara veli kaynaklı sorunlar çerçevesinde bakıldığında aile içi şiddetin, öğrencilerin çoğunun ailesinde var olduğu, Suriyeli öğrencilerin içinde çocuk işçi sayısının oldukça fazla olduğu ve öğrenci velilerinin basit okul gereçlerini bile devletten beklediği gibi sorunlar ortaya çıkmıştır. Aile ortamında yaşanan problemlerin öğrencilerin olumsuz yönde davranış geliştirmelerine etki ettiği söylenebilmektedir. $\mathrm{Bu}$ sorunları yaşayan öğrencilerin, daha temel ihtiyaçlarının bile karşılanamamasından ve huzurlu bir aile ortamına sahip olamamalarından dolayı okulu ve dersleri çok dikkate almadıkları, eğitimleri için çaba göstermedikleri söylenebilmektedir. Araştırmanın bu sonucuna benzer olarak Hek (2006), araştırmasında ev ile okul arasındaki bağların geliştirilmesinin gerekliliğine vurgu yapmıştır. Göçün toplumsal yapıya etkisi göçün gerekçesine göre farklılaşmaktadır. Özellikle zorunlu göçlerde göçmenlerin ülkeye hazırlıksız gelmesi, geldikleri yeni yerleşim biriminde sosyo-ekonomik ve psikolojik birtakım problemler yaşamalarına neden olmaktadır (Tümtaş ve Ergun, 2016). Bu bağlamda düşünüldüğünde Suriye'den göç eden ailelerin birçok sorun alanı ile karşı karşıya kaldıkları ve savaş nedeniyle göç etmiş olmanın verdiği psikolojik etkilerin çocukları da olumsuz yönde etkilediği söylenebilmektedir. Suriyeli öğrencilerin eğitimleri ile ilgili ortaya çıkan sorunlar çerçevesinde bakıldığında, bu öğrencilerin şiddete meyilli davranış sergiledikleri, öğretmenlerin bu davranışları iyileştirmede zorluklar yaşadıkları, iletişim sorunları yaşadıkları için uyum sağlamada zorlandıkları ve bunun da eğitim süreçlerini olumsuz yönde etkilediği gibi sorun alanları ortaya çıkmıştır. İlkokul yöneticileri ve sınıf öğretmenlerinin görüşme sorularına verdikleri yanıtlardan yola çıkarak bu sonucu desteklemek mümkündür. Araştırmanın yürütüldüğü okul kaynaştırma projesi kapsamında yer alan bir okul olduğu için görüşülen sınıf öğretmenleri, Suriyeli öğrencilerin sadece akademik başarıları ile ilgilenmediklerini daha çok eğitim ve uyum sürecinde ilerleme kaydetmeye çalıştıklarını ve bu öğrencilerin ailelerinin eğitimi önemsemeyip, ilgisiz davranmalarının önemli bir sorun olduğunu belirtmişlerdir. Bu araştırmada ortaya çıkan sorun alanları değerlendirildiğinde, Suriyeli öğrencilerin yaşadıkları ekonomik, sosyo-kültürel ve psikolojik problemlerin bu öğrencilerin eğitim hayatlarında hem de uyum süreçlerinde sorunlara neden olduğu söylenebilmektedir. Araştırmanın bu sonucuna benzer olarak Graham, Minhas ve Paxton (2016), Bunar (2019), Kanu (2008), araştırmalarında mülteci öğrencileri göç sonrası travma yaşadıkları ve psikososyal soruları olduğu için uyum sağlamada zorlandıkları bulgularına ulaşmışlardır.

Araştırmanın ikinci alt amacında, ilkokul yöneticileri ve sınıf öğretmenlerinin görüşlerine göre Suriyeli öğrencilerin yaşadıkları sorunların altında yatan nedenler incelenmiş̧tir. Araştırmanın sonucunda elde edilen verilere göre sorunların altında yatan nedenlerin veli kaynaklı, sistemsel, ekonomik, sosyal ve psikolojik nedenler olduğu ortaya çıkmıştır. Suriyeli öğrencilerin yaşadıkları sorunların nedenleri bütünsel bir bakış açısıyla incelenecek olursa, sorunlar ve nedenlerin birbirini etkileyen olgular olduğu söylenebilir. Öğrencilerin dil sorunlarının olması başlı başına bir sorun alanıyken, dil bilmemelerinin iletişim sorunları yaşamaları ve içe kapanık davranışlar sergilemelerinin bir nedeni olduğu ifade edilebilir. Aynı şekilde öğrencilerin yaşıtları ile aynı sınıfta olmamaları bir sorunken, bulundukları sınıfa kendilerini ait hissetmemelerinin bir nedeni olduğu söylenebilir. Bu görüşü ilkokul yöneticileri ve sınıf öğretmenlerinin yanıtları ile desteklemek mümkündür. Araştırmanın sonucunda ilkokul yöneticileri ve sınıf öğretmenlerinin en çok üzerinde durdukları nedenlerin, Suriyeli öğrencilerin bölgelere düzenli dağıtılmamaları, ülkeye plansız şekilde alınmış olmaları ve kültürel farklılık olduğu ortaya çıkmıştır. İlkokul yöneticileri ve sınıf öğretmenleri kültürel farklılık nedeniyle, Suriyeli öğrencilerin arkadaşlık kurmakta zorlandıklarını, öncelikle kendi uyruklarından olan çocuklarla arkadaşlık kurduklarını belirtmişlerdir. Katılımcılardan alınan yanıtlara göre ailelerin eğitimsiz oluşu, eğitime olan ilgisizlikleri ve öğrencilerin yaşamak zorunda oldukları kalabalık ev ortamı, eğitim sürecinde yaşanan sorunların altında yatan belirgin nedenlerinden bazıları olduğu söylenebilir.

Araştırmanın üçüncü alt amacında, ilkokul yöneticileri ve sınıf öğretmenlerinin görüşlerine göre yaşanılan sorunlara ilişkin çözüm önerileri incelenmiştir. Araştırmanın sonucunda ilkokul yöneticileri 
ve sinıf öğretmenlerinin belirttikleri çözüm önerileri; ülkelerine geri gönderilmeleri, nüfus kontrolü, ailelere eğitim, bölgelere ve okullara eşit dağıtılmaları, okullara gönderilmeden önce dil eğitimi almaları, Suriyeli öğrenciler için özel bir planın olması şeklinde sıralanabilir. Araştırma sırasında görüşülen tüm katılımcıların çözüm önerisi olarak ilk sundukları seçenek Suriyelilerin ülkelerine geri gönderilmeleri gerektiği olmuştur. Görüşülen ilkokul yöneticileri ve sınıf öğretmenleri ülkede bu kadar fazla Suriyeli nüfusun varlığını sakıncalı bulduklarını, eğitim verdikleri öğrencilerden verim alamadıklarını, Suriyeli öğrenciler için uygulanacak özel bir eğitim planı olmadığı için kendilerini yetersiz bulduklarını ve bu sebeplerden dolayı ülkelerine geri gönderilmelerinin yerinde bir karar olacağını belirtmişlerdir. Yaşadıkları zamanı daha verimli kılabilmek adına özellikle üstünde durdukları çözüm önerilerinin, okullara gönderilmeden önce dil eğitimi almaları gerektiği, Geçici Eğitim Merkezleri (GEM) gibi merkezlerde akranlarıyla eğitim görmeleri, okullara ve bölgelere dağıtımlarının kontrollü ve olabildiğince eşit yapılması olduğu söylenebilmektedir. Araştırmada katılımcılar tarafindan sunulan bir diğer çözüm önerisi ise ailelere eğitim verilmesi gerektiği yönünde olmuştur. Benzer şekilde Matthews (2008), Hek (2006) tarafından yapılan araştırmalarda da ailelere destek verilmesi ve okul-aile işbirliğinin gerekliliği üzerinde durulmuştur. Suriyeli öğrencilerin Türk eğitim sisteminde yaşadıkları sorunlara ilişkin bir diğer çözüm önerisi olarak okul-aile işbirliğinin güçlendirilmesi gerektiği söylenebilmektedir.

Araştırma sonucunda elde edilen bulgular bir bütün halinde değerlendirilirse, görüşülen ilkokul yöneticileri ve sınıf öğretmenlerinin araştırma sorularına verdikleri yanıtlar ışı̆̆ında okullarda eğitim gören Suriyeli öğrencilerin öncelikle dil sorunu olmak üzere, uyum ve başarı sorunları yaşadıkları söylenebilmektedir. Bu öğrencilerin savaş görmüş çocuklar olması onların psikolojilerini ciddi derecede etkilemiş olup; bunun sonucunu da davranışlarında görmek mümkündür. Bu öğrencilerin daha sağlıklı bir eğitim sürecinden geçmeleri için elde bulunan imkânların yeterli olmadığı, onlara özel bir programın olması gerektiği, ailelerin bilinçlendirilmesi ve eğitim sürecine katılması gerektiği görüşülen ilkokul yöneticileri ve sınıf öğretmenleri tarafından belirtilen görüşler arasındadır. Sınıf öğretmenleri uyum sürecinde yeterli verimi alamadıklarını ve öğrencilerin bölgelere dağıtılması konusunda adaletsizlikler olduğunu belirtmişlerdir. Bu görüşler 1şığında Suriyeli öğrencilerin eğitim süreçlerini iyileştirmek amacıyla daha düzenli ve programlı çalışılmasına ihtiyaç duyulduğu da söylenebilir. Araştırmada gözlem yoluyla elde edilen bulgularla ilkokul yöneticileri ve sınıf öğretmenlerinin görüşlerinin örtüştüğü görülmektedir.

Yapılan araştırma sonucunda ortaya çıkan bulgulara göre öğretmenler aldıkları hizmet içi eğitimlerin yetersiz olduğunu belirtmiştir. Araştırmanın bu bulgusuna yönelik olarak yönetici ve öğretmenler, üniversitelerle işbirliği yaparak sorunların çözümlerine yönelik seminerlere katılabilir ya da bu seminerlerin okullarında verilmesini sağlayabilirler. Araştırmada Suriyeli öğrencilerin ailelerinin eğitime ilgisiz oldukları ortaya çıkmıştır. Bu bağlamda, Suriyeli öğrencilerin ailelerini eğitim sürecine katabilmek için aile eğitimleri düzenlenebilir. Araştırma sonucunda Suriyeli öğrencilerin davranışsal sorunlar yaşadıkları ortaya çıkmıştır. Bu bulguya yönelik olarak, Suriyeli öğrencilerin davranış problemlerini çözebilmek amacıyla psikolojik destek programları geliştirilebilir ve var olanlar artırılabilir. Araştırma sonucunda elde edilen bulgulara göre Suriyeli öğrencilerin eğitime karşı isteksiz oldukları sonucu ortaya çıkmıştır. Bu bağlamda Suriyeli öğrencilerin katılımlarını sağlayacak sosyal etkinlikler düzenleyerek okulu ve eğitimi sevdirecek çalışmalar yürütülebilir. Araştırma bulgularında Suriyeli öğrencilerin okullara eşit dağıtılmadığı ortaya çıkmıştır. Araştırmanın bu bulgusuna yönelik olarak yöneticiler bu sorunu çözmek adına İlçe Milli Eğitim Müdürlüğü'yle koordineli bir çalışma yürütebilirler. Bu araştırmada Suriyeli öğrencilerin yaşadıkları en belirgin sorunun dil sorunu olduğu ortaya çıkmıştır. Dil sorununu çözebilmek amacıyla oluşturulmuş olan dil öğretim sınıflarının sayısı artırılabilir. Benzer bir araştırma farklı illerde ya da Türkiye genelinde farklı eğitim kademelerindeki yönetici ve öğretmenlerle yapılabilir. Daha detaylı bilgiler elde edebilmek adına veli ve öğrenci görüşlerine de yer verilebilir. Türk eğitim sisteminde yer alan Suriyeli öğrencilerin ve velilerinin mutluluk ve tutumlarına yönelik farklı araştırmalar yürütülebilir.

\section{Kaynakça}

Akalın, A. T. (2016). Türkiye’ye gelen Suriyeli göçmen çocukların eğitim sorunları (Yüksek lisans tezi). İstanbul Aydın Üniversitesi, İstanbul. 
Almadani, D. S. (2018). Syrian refugee students academic and social experinces in American public schools (Doctoral Dissertation). DePaul University, ABD, https://via.library.depaul.edu. adresinden indirilmiştir (Erişim Tarihi: 17.11.2019).

Bajaj, M., \& Bartlett, L. (2017). Critical transnational curriculum for immigrant and refugee students. Curriculum Inquiry Journal, 47, 25-35.

Başar, M., Akan, D., \& Çiftçi, M. (2018). Mülteci öğrencilerin bulunduğu sınıflarda öğrenme sürecinde karş1laş1lan sorunlar. Kastamonu Ĕ̈itim Dergisi, 26(5), 1571-1578

Bhugra, D. (2004). Migration, distress and cultural identity. British Medical Bulletin, 69(1), 129-141.

Bunar, N. (2019). Education of refugee and asylum-seekin children. Oxford Research Encyclopedias, $10,1-10$.

Büyüköztürk, Ş., Çakmak, E. K., Akgün, Ö. E., Karadeniz, Ş., \& Demirel, F. (2014). Bilimsel araştırma yöntemleri. Ankara: PegemA.

Creswell, J. W. (2013). Nitel araştırma yöntemleri. (M. Bütün, M. ve S. Demir, Çev.). Ankara: Siyasal.

Creswell, J. W. (2017). Nitel araştırmacılar için 30 temel beceri. (H. Özcan, Çev.). Ankara: Anı.

Erdem, C. (2017). Sınıfında mülteci öğrenci bulunan sınıf öğretmenlerinin yaşadıkları öğretimsel sorunlar ve çözüme dair önerileri. Medeniyet Eğitim Araştırmaları Dergisi, 1(1), $26-42$.

Göç İdaresi Genel Müdürlüğü (2019). Göç İdaresi Genel Müdürlügü güncel veriler https://www.goc.gov.tr/gecici-koruma5638 adresinden indirilmiştir (Erişim tarihi: 18.09.2019).

Graham, H. R., Minhas, R. S., \& Paxton, G. (2016). Learning problems in children of refugee background: A systematic review. American Academy of Pediatrics, 137(6), 1-15.

Guba, E. G., \& Lincoln, Y. S. (1982). Epistemological and methodological bases of naturalistic inquiry. Educational Communication and Technology Journal, 30(4), 233-252.

Güllüpınar, F. (2012). Göç olgusunun ekonomi-politiği ve uluslararası göç kuramları üzerine bir değerlendirme. Yalova Sosyal Bilimler Dergisi, 2(4), 53-85.

Hek, R. (2006). The role of education in the settlement of young refugees in the UK: The experiences of young refugees. Practice Social Work in Action, 17, 157-171.

İstanbul İl Milli Eğitim Müdürlüğü (2019). Suriyeli çocukların eğitim- ögretimi konulu koordinasyon toplantısı.https://istanbul.meb.gov.tr/www/suriyeli-cocuklarin-egitim-ogretimi-konulukoordinasyon-toplantisi/icerik/1459 adresinden indirilmiştir (Erişim tarihi: 09.09.2019).

Kanu, Y. (2008). Educational needs and barriers for African refugee students in Manitoba. Canadian Journal of Education, 31(4), 915-940.

Karakoç, R. (2011). Göç edenlerin kentsel bütünleşme ve siyasal katılma durumlarına yönelik bir araştırma: Konya örneği. Sosyal Ekonomik Araştırmalar Dergisi, 11(21), 241-262.

Karasar, N. (2014). Bilimsel araştırma yöntemi: Kavramlar, ilkeler, teknikler. Ankara: Nobel.

Kardeş, S., \& Akman, B. (2018). Suriyeli sığınmacıların eğitimine yönelik öğretmen görüşleri. Illkögretim Online, 17(3), 1224-1237.

Koehler, C., \& Schneider, J. (2019). Young refugees in education: the particular challenges of school systems in Europe. Comparative Migration Studies, 28, 1-20.

Matthews, J. (2008). Schooling and settlement: Refugee education in Australia. International Studies in Sociology of Education, 18, 31-45.

Merriam, S. (2015). Nitel araştırma desen ve uygulama için bir rehber. (S. Turan, Çev.). Ankara: Nobel.

Milli Eğitim Bakanlığı, (2019). Suriyeli çocukların Türk eğitim sistemine entegrasyonlarının desteklenmesi projesi (PICTES). https://pictes.meb.gov.tr/pys/login/ adresinden indirilmiştir (Erişim tarihi: 21.01.2020).

Miles, M. B., \& Huberman, A. M. (1994). Qualitative data analysis: An expanded sourcebook. Thousand Oaks, California: Sage.

Patton, M. Q. (2014). Nitel araştırma ve değerlendirme yöntemleri. M. Bütün ve S. B. Demir (Edt.). Ankara: Pegem Akademi.

Sağlam, S. (2017). Türkiye'de iç göç olgusu ve kentleşme. Hacettepe Üniversitesi Türkiyat Araştırmaları, 5, 33-44.

Sağlam, H. İ., \& Kanbur, N. İ. (2017). Sınıf öğretmenlerinin mülteci öğrencilere yönelik tutumlarının çeşitli değişkenler açısından incelenmesi. Sakarya University Journal of Education, 7(2), 310323.

Sayın, Y., Usanmaz, A., \& Aslangiri, F. (2016). Uluslararası göç olgusu ve yol açtığ1 etkiler: Suriye göçü örneği. KMÜ Sosyal ve Ekonomik Araştırmalar Dergisi, 18(31), 1-13. 
Şensin, C. (2016). Sinıf ögrretmenlerinin Suriye’den göçle gelen ögrrencilerin eğitimlerine ilişkin görüşlerinin değerlendirilmesi (Yüksek lisans tezi). Uludağ Üniversitesi, Bursa.

Tanoğlu, A. (1969). Nüfus ve yerleştirme. İstanbul: İstanbul Üniversitesi Yayınları.

Terzi, E. (2012). Türkiye'de göç olgusu, göç edenlerin kentlere olan etkileri ve çözüm önerileri. Kafkas Üniversitesi Iktisadi ve İdari Bilimler Fakültesi Dergisi, 3(3), 163-184.

Tunç, A. (2015). Mülteci davranışı ve toplumsal etkileri: Türkiye'deki Suriyelilere ilişkin bir değerlendirme. Tesam Akademi, 2(2), 29-63.

Tümtaş, M. S., \& Ergun, C. (2016). Göçün toplumsal ve mekansal yapı üzerindeki etkileri. Süleyman Demirel Üniversitesi İktisadi ve İdari Bilimler Fakültesi Dergisi, 21(4), 1347-1359.

Türnüklü, A. (2001). Eğitim bilim alanında aynı araştırma sorusunu yanıtlamak için farklı araştırma tekniklerinin birlikte kullanılması. Eğitim ve Bilim, 26(120), 8-13.

Yıldırım, A., \& Şimşek, H. (2016). Sosyal Bilimlerde Nitel Araştırma Yöntemleri. Ankara: Seçkin.

\section{Extended Abstract}

\section{Introduction}

It is known that various migrations took place in all periods of human history. Migration is the geographical displacement of people from one place to another, for some or all of their lives, temporarily or permanently (Bhugra, 2004). Migrations also have multiple effects on immigrant families. The most affected group is of course children. Indeed, Turkey has been undergoing since 2011 immigration such an event. Civil war in Syria, unemployment, oppressive government, excessive increase of food prices from these reasons, Syrian citizens began to migrate to various countries and especially Turkey (Sayın, Usanmaz \& Aslangir of 2016). The number of Syrian citizens in Turkey 3,687,244 as of November 21, 2019 (Directorate General of Migration Management, 2019). According to April 2019 data, there were $1,733,034$ Syrian students, 655,075 of them $(62.53 \%)$ had access to education (Ministry of National Education, 2019). According to 2017 data, approximately 130,000 Syrian students receive education in Istanbul (Istanbul Directorate of National Education, 2019). Republic of Turkey services some of the lackness of immigrants such as the education of children of Syrian migrant families. And also it is thought that they still have multidimensional needs and problems such as language, housing, health, and education. None of the researches was conducted with students in a large and cosmopolitan district such as Beyoğlu, Istanbul. It can be said that it is necessary for both Syrian and other students in Istanbul to reveal the educational problems of students, to develop solutions, and to find the causes of the problems. The aim of this research is to examine the problems of Syrian refugee students who are at the public school in the light of primary school administrators' and teachers' opinions. Within the framework of this main purpose, the following questions were sought in the study.

According to primary school administrators and classroom teachers, Syrian students;

1. What are the problems they experienced in the Turkish education system?

2. What are the underlying reasons for the problems experienced?

3. What are the solutions to these problems?

\section{Methodology}

The case study design, one of the qualitative research designs, was used in conducting the research. The research was carried out in Beyoğlu district of Istanbul province in 2019. The participants of the study were selected using the criterion sampling method. In the study, the researchers interviewed twelve classroom teachers and two primary school administrators. Interviews and observations were made in order to reveal the experiences and opinions of classroom teachers and primary school administrators regarding the research. Data was analyzed by content analysis method.

\section{Findings and Discussion}

As a result of the research, it was revealed that the leading problem of Syrian students was the language problem. Similar to these results, research by Graham, Minhas, and Paxton (2016), Bunar (2019), and Almadani (2018) found that refugee students have problems in language learning. Results of the research within the framework of parent-related problems, problems such as domestic violence exist in the families of most of the students, the number of child workers among Syrian students is quite high, and the parents of students expect even simple school supplies from the state. According to the data obtained 
as a result of the study, it has been revealed that the underlying reasons for the problems are parents, system, economic, social, and psychological reasons. As a result of the research, the solution suggestions stated by primary school administrators and classroom teachers; repatriation of Syrians to their country, population control, education for families, equal distribution of regions and schools, language training before being sent to schools, and a special plan for Syrian students. The number of language teaching classes established to solve the language problem can be increased. Administrators and teachers can participate in courses. Similar research across different provinces in Turkey can be made at different educational levels.

\footnotetext{
*Araştırma için, Aydın Adnan Menderes Üniversitesi Eğitim Araştırmaları Etik Kurulu'ndan 25.12.2018 tarih ve 2018/13 sayılı kararı ile etik kurul onayı alınmıştır.

* Bu çalışmada bulunan yazarların katkı oranları: Gizem Alkalay \%50, Bilgen Kıral \%35, Ali Rıza Erdem \%15
} 